



\section{Russia and the Post 2012 Climate Regime}

Emission Trends, Commitments and Bargains

Anna Korppoo, George Sakonov, Oleg Lugovoy

TemaNord 2010:584 


\section{Russia and the Post 2012 Climate Regime}

Emission Trends, Commitments and Bargains

TemaNord 2010:584

(C) Nordic Council of Ministers, Copenhagen 2010

ISBN 978-92-893-2133-4

Print: Kailow Express ApS

Copies: 200

This publication has been published with financial support by the Nordic Council of Ministers. But the contents of this publication do not necessarily reflect the views, policies or recommendations of the Nordic Council of Ministers.

Printed on environmentally friendly paper

This publication can be ordered on www.norden.org/order. Other Nordic publications are available at www.norden.org/publications

Printed in Denmark

\section{Nordic Council of Ministers}

Ved Stranden 18

DK-1061 København K

Phone (+45) 33960200

Fax (+45) 33960202

\author{
Nordic Council \\ Ved Stranden 18 \\ DK-1061 København K \\ Phone (+45) 33960400 \\ Fax (+45) 33111870
}

\section{Nordic co-operation}

Nordic co-operation is one of the world's most extensive forms of regional collaboration, involving Denmark, Finland, Iceland, Norway, Sweden, and three autonomous areas: the Faroe Islands, Greenland, and Åland.

Nordic co-operation has firm traditions in politics, the economy, and culture. It plays an important role in European and international collaboration, and aims at creating a strong Nordic community in a strong Europe.

Nordic co-operation seeks to safeguard Nordic and regional interests and principles in the global community. Common Nordic values help the region solidify its position as one of the world's most innovative and competitive. 


\section{Content}

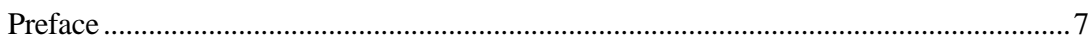

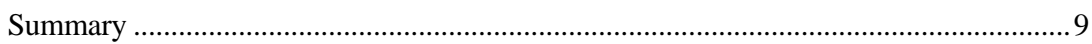

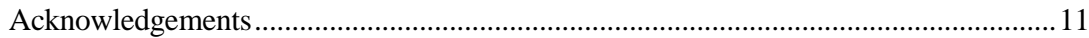

Section 1. Economic development and GHG emission projections in Russia ................13

1. Russia's carbon emissions: drivers and factors .............................................................15

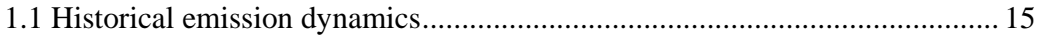

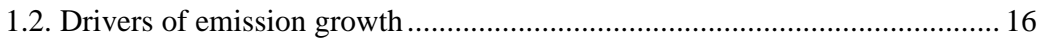

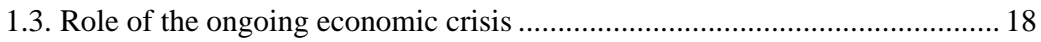

2. Scenarios of economic development ........................................................................... 19

2.1 Concept of long-term socio-economic development ..................................... 20

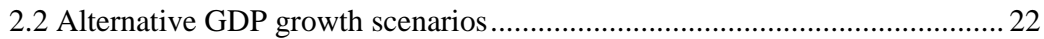

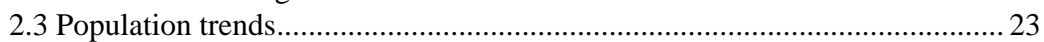

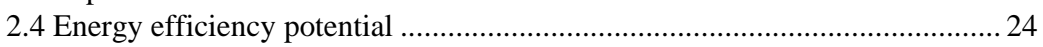

2.5 Energy production and export projections..................................................... 26

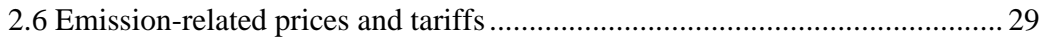

2.7 Renewable energy potentials for electricity and heat production .................... 30

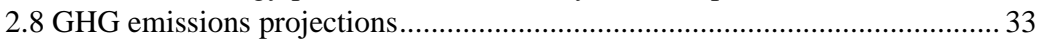

Section 2. Implications of the Russian participation for the Future Climate Regime ... 45

1. The Elements Relevant to the Comparability of the Russian Pledge ...........................47

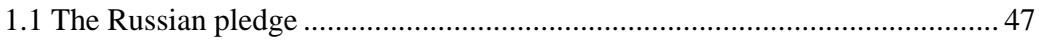

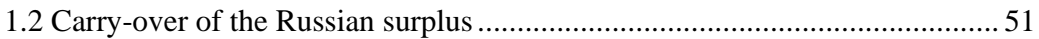

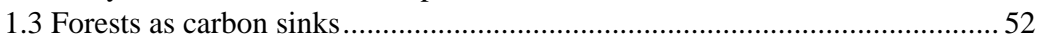

2. Balancing the Russian pledge within a future agreement ...........................................57

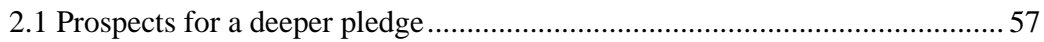

2.2 Balancing the architecture of the agreement ................................................. 59

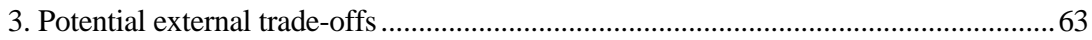

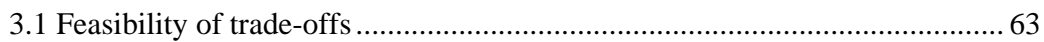

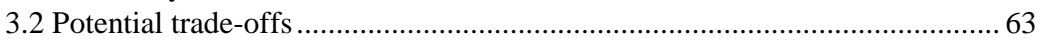

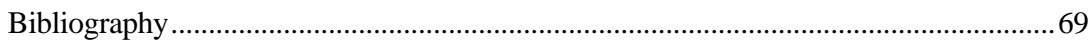

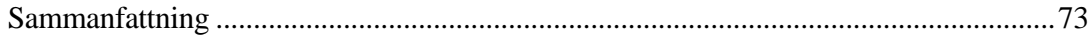

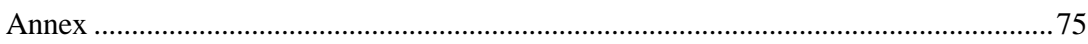

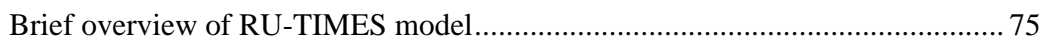





\section{Preface}

The Nordic Ministers of Environments established the Nordic COP 15 Group early in 2008. In January 2010 the group was renamed to the Nordic Ad Hoc Group on Global Climate Negotiations. The main tasks of the group are to prepare reports and studies, conduct relevant meetings and organize conferences supporting the Nordic negotiators in the UN climate negotiations. The overall aim of the group is to contribute to a global and comprehensive agreement on climate change with ambitious emission reduction commitments.

The authors are responsible for the content of this report. The views expressed and conclusions drawn do not necessarily reflect those of the Nordic Ad Hoc Group on Global Climate Negotiations.

Stockholm August 2010

Olle Björk

Chair of the Nordic Ad Hoc Group

on Global Climate Negotiations 



\section{Summary}

The post-2012 negotiation process under the frameworks of the UNFCCC and Kyoto Protocol posed a lot of issues related to future commitments of developed as well as developing countries with regard to reduction of global greenhouse gas emissions. The outcome of the Copenhagen negotiations round - the Copenhagen Accord - suggests an overall goal of limiting global warming below $2^{\circ} \mathrm{C}$ in the $21^{\text {st }}$ century. According to the IPCC, this would require the Annex I Parties to reduce their GHG emissions by $25-40 \%$ by 2020.

Russia was the third largest emitter of GHG emissions in the world after China and USA in 2007. The national emissions substantially declined since the collapse of the Soviet system from 3,3 $\mathrm{Mt} \mathrm{CO}_{2} \mathrm{e}$ in 1990 to 2,2 $\mathrm{Mt} \mathrm{CO}_{2} \mathrm{e}$ in 2007; the 2009 economic recession generated a further emission cut. Under the Copenhagen Accord Russia has pledged to limit its emissions 1525\% below 1990 level by 2020 .

The first section of this report analyzes the development trends and conditions of the Russian economy, specifically its energy sector. It also reviews the projections of carbon emissions by 2020 and beyond in the context of the government's scenarios of economic development. The main conclusions are:

- Scenarios predict growth of emissions, however, Russia still has enormous potential for further emission reduction, especially in the inefficient energy and communal sector, metallurgical and other industries, as well as increase of renewable energy and carbon sequestration by forests.

- Active policy in energy efficiency, modernization, innovation spheres would be likely to lead to emission stabilization 27-35\% below 1990 levels by 2020 . 
- The RU-TIMES model focusing on electricity and heat production shows that strict caps on emissions and links to the global carbon market could generate a decline of emissions from this sector by approximately 50\% below 1990 level by 2020 and 54\% by 2030 .

The second section of the report focuses on Russia's position in the negotiation process for a post-2012 climate regime, including the emission limitation pledge, carry-over of the surplus of the assigned amounts (AAUs) beyond 2012 and the forest carbon sinks. The main findings include:

- There are various views on the Russian business-as-usual emission trend; however, taking into account the economic crisis, 30-35\% below 1990 by 2020 seems to be a likely path. As a result, the current $-25 \%$ pledge can be considered as weak.

- Combined with the carry-over of the surplus and the forest sink accounting rules advocated by Moscow, Russia's pledge under the Copenhagen Accord would require other Annex I countries to accept targets beyond their levels of comparable effort across the group in order to achieve the aggregate level of reductions recommended by the IPCC.

- At the same time, recognition of the fact that Russia's emissions declined since 1990 and 'full” accounting of forests are political priorities for Moscow.

- Potential trade-offs to bring Russia on board in the climate negotiations have been discussed (and used during the Kyoto Protocol ratification process), however, the current unclear stage of negotiations is too early for such swaps. Given the links to future global energy policy-making, it ought to also be asked why Russia should not join the regime without such trade-offs.

This report is based on a study conducted prior to the Copenhagen climate negotiation round in December 2009, and updated as of June 2010. However, the analysis does not comprehensively represent all the latest developments in the international climate regime. 


\section{Acknowledgements}

The authors would like to thank the Environmental Defense Fund and Institute for Economy in Transition for their kind support in analysis of carbon emission trends in Russia and modeling of the emission scenarios in Russia.

We also thank the Krzhyzhanovsky's Institute of Energy (Moscow) and, personally, Mikhail Saparov for their highly professional advise on the Russian energy sector development, economic and environmental impacts of various policies and measures; as well as Thomas Spencer (the Finnish Institute of International Affairs) for his contribution to the Russian LULUCF policy analysis, and Andrew Jones (the Finnish Institute of International Affairs) for editing the report.

Our special thanks to Vladimir Berdin (International Sustainable Energy Development Centre), Sergey Drobyshevsky (IET), Inna Gritsevich (CENEF/ WWF-Russia), Alexey Kokorin (WWF-Russia), Andrey Stetsenko (Moscow State University) and other experts for their valuable comments and critical views on our findings.

Finally, we would like to express our gratitude to the Nordic Ad Hoc Group on Global Climate Negotiations (former COP 15 group) of the Nordic Council of Ministers for funding this work. 



\section{Section 1. Economic development and GHG emission projections in Russia}

Authors:

Dr. George Safonov, State University - Higher School of Economics/ Environmental Defense Fund

Dr. Oleg Lugovoy, Environmental Defense Fund 



\section{Russia's carbon emissions: drivers and factors}

\subsection{Historical emission dynamics}

Historically, Russia has been one of the largest sources of carbon emissions in the world. During the Soviet era, Russia was responsible for around onefifth of global $\mathrm{CO}_{2}$ emissions coming from energy consumption, thus the country has responsibility for a large share of cumulative anthropogenic carbon emissions into the atmosphere. Even after the economic collapse of 1990s and ensuing sharp drop in industrial production, Russia is still one of the leading greenhouse gas (GHG) emitters. In 2007, Russia was the third largest emitter of $\mathrm{CO}_{2}$ from the energy sector after China and USA, and the fourth largest if the EU is considered a single emitter (see Figure 1.1).

Russian GHG emissions collapsed by 40\% in 1990-1998 following the dramatic decline in energy consumption and industrial production. During 1999-2007 emissions grew by $10 \%$ up to 66\% of 1990 level (see Figure 1.2).

According to recent expert estimates (official data are not available yet), the global financial and economic crisis of 2008-2009 led to a 7-8\% decline in Russian emissions, down to 37\% or more below the 1990 level.

Analysis of the historical data allows for identification of the main drivers of and factors in national GHG emissions, which are important for the modeling and projection of emissions until 2020 and beyond. 


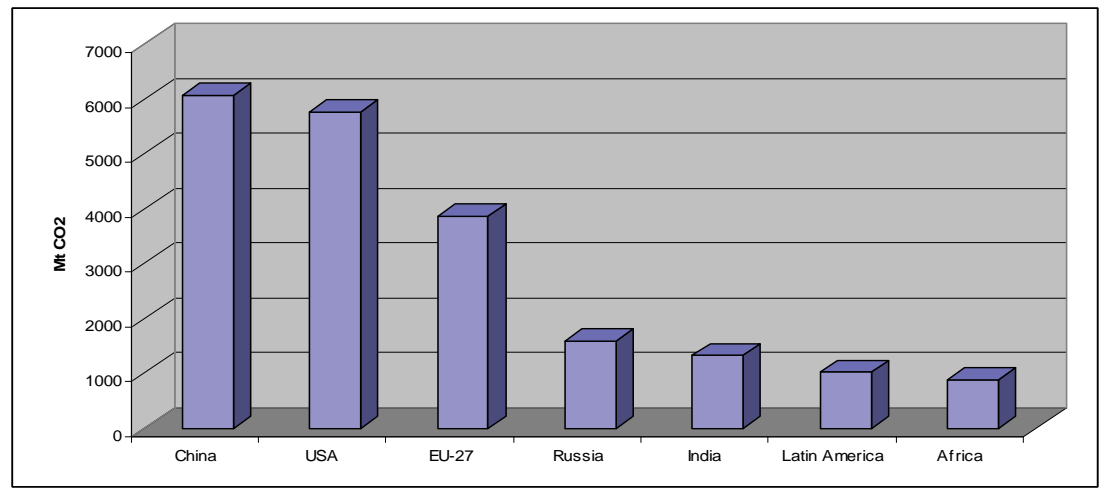

Figure 1.1. Energy-related $\mathrm{CO}_{2}$ emissions by selected countries and regions, 2007 (Mt $\mathrm{CO}_{2}$ /year). Sources: IEA, UNFCCC, 2009.

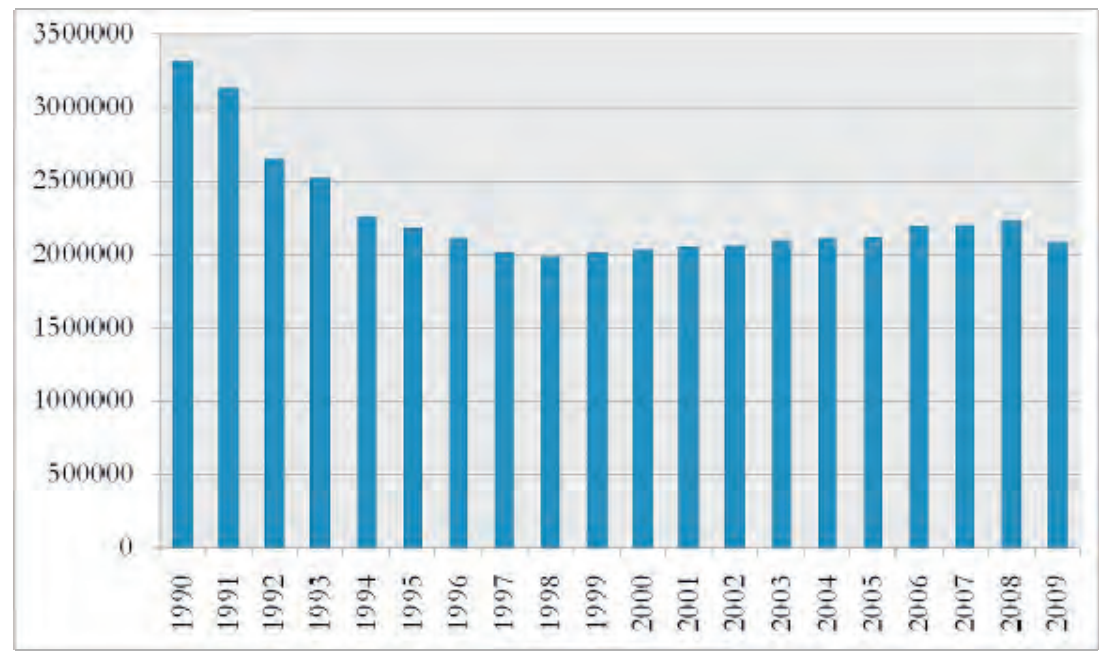

Figure 1.2. Russia's greenhouse gas emissions, 1990-2007 (tons of $\mathrm{CO}_{2} \mathrm{e}$ ). Sources: for 1990-2007 - UNFCCC (2009), for 2008-2009 - authors' estimates.

\subsection{Drivers of emission growth}

The following leading drivers of GHG emissions in Russia are relevant:

- GDP growth. This reflects the overall economic performance of the country, consumption of energy resources, governmental and households spending, etc. 
- Economic structure. The sectoral structure of the economy plays a significant role in energy consumption and hence GHG emissions. For instance, sharp growth of the services sector in the post-Soviet economy of Russia (from $25 \%$ in 1990 to over $50 \%$ in 2000 and on) led to a structural shift-based reduction of energy use.

- Structure of industrial production. A shift towards heavy industries and a decline in low-carbon industries (light industry, machinery, etc.) increases energy consumption. Thus, the policies aimed at the elimination of the dominance of heavy industries plays a positive role in terms of emission reduction.

- Energy policy and fuel prices. These measures directly influence fossil fuel consumption, and hence the carbon emissions.

- Technological shifts. In Russia technological improvements play substantial role in promoting low carbon development and reduction of energy consumption, primarily via substitution of outdated Soviet technologies for new more efficient ones.

Various drivers have had different roles in decreasing or increasing Russian carbon emissions since 1990. As a result, different sectors had different emissions dynamics in 1990 than the present, as shown in Table 1.1. The main development has been the decline of the share of the agricultural sector, while the importance of industrial processes as an emissions source has increased slightly.

Table 1.1. Breakdown of GHG emissions in Russia, 1990-2007.

\begin{tabular}{lrrrrrr}
\hline Category & $\mathbf{1 9 9 0}$ & $\%$ & $\mathbf{2 0 0 0}$ & $\%$ & $\mathbf{2 0 0 7}$ & $\%$ \\
\hline 1 Energy & 2707175 & 82 & 1661199 & 82 & 1785679 & 81 \\
2 Industrial Processes & 246750 & 7 & 170188 & 8 & 208071 & 10 \\
3 Solvent and Other Product Use & 562 & 0 & 523 & 0 & 541 & 0 \\
4 Agriculture & 309972 & 9 & 146232 & 7 & 134709 & 6 \\
6 Waste & 54868 & 2 & 52288 & 3 & 63818 & 3 \\
Total & 3319327 & & 2030431 & & 2192818 & \\
\hline
\end{tabular}

Source: UNFCCC, 2009. 


\subsection{Role of the ongoing economic crisis}

As has been the case in practically every aspect of Russian policy, the global economic crisis has had a major impact on the national energy efficiency plans and programs.

On one hand, the crisis affected the government's approach to energy efficiency reform. Unlike the business-as-usual approach seen in previous years, more aggressive policy measures were adopted. For example, the government's anti-crisis plan included requirements for recipients of funds from the stimulus package to have an energy efficiency plan.

On the other hand, the crisis forced substantial reductions in corporate investment programs, including modernization of energy infrastructure and energy transportation networks. This is particularly true of the electricity sector, which saw a 4.5\% drop in demand in 2009 as well as the other sectors affected by the global decline in demand, such as metallurgy and the chemical industry. 


\section{Scenarios of economic development}

One of the main difficulties in modeling carbon emissions in Russia is the lack of data and contradiction between official and expert estimates of various economic, energy and other indicators, especially in the long-term.

At the moment, there are a number of sources of information required for elaboration of scenarios for GHG emission projections, such as:

- The Concept of Long-term socio-economic development of Russia, adopted by the government in December 2008 and aimed at 2020;

- The Government's Energy Strategy - 2030; adopted in 13 November 2009;

- The federal law on energy saving and energy efficiency, enacted 23 November 2009, and the State program on energy efficiency improvement, prepared by the Ministry of Economic Development with the participation of the Ministry of Energy and other governmental bodies, yet to be adopted;

- Anti-crisis action plans and other measures by the Government, adopted in 2008 and in force until 2010, including various measures aimed at energy efficiency improvement and energy saving;

- General scheme for electricity sector development, adopted by the government in February 2008;

- Forecasts by International Energy Agency (IEA), World Bank, IMF, Russian expert institutes, etc.

Because these sources very often and substantially contradict one another, the most reliable assumptions for our projections had to be chosen based on our experience and knowledge of the Russian economy and energy sector. 


\subsection{Concept of long-term socio-economic development}

In September 2008, the Ministry of Economic Development (MED) of the Russian Federation officially announced the "Concept of Long-term SocioEconomic Development of the Russian Economy” (hereafter, the "Concept”). This document describes three scenarios of economic development up to 2020 with some estimates until 2030.

According to the most optimistic "innovative" scenario, the Russian economy will on average grow by $6.5 \%$ per annum from 2008 to 2020 . This scenario is considered to be the target scenario by the Russian government. It assumes wide use of comparative advantages of the Russian economy in the energy, transport and agriculture sectors, significant development of the knowledge-based economy, as well as development of human capital.

The "Inertial" scenario is the most conservative, with the slowest average growth per year at $4.6 \%$ throughout the period and less then $4 \%$ during 2011-2020. In this scenario a raw-materials exporting model is assumed to be the main model of economic development, with few reforms and decreasing growth of energy and raw-materials exports.

The "Energy and Raw Materials" scenario assumes an average 5.5\% economic growth per year during 2008-2020. In this scenario a wide use of comparative advantages of the Russian energy sector is assumed: the growth of energy and raw material exports and an increase in the quality grade of products. According to this scenario, innovative technologies will be applied in mining and processing, the power-sector, metallurgy, chemical industry, development of transport infrastructure, diversification of raw materials and energy exports; relatively slow development of high-tech sector compared to the "Innovative" scenario is assumed.

As it is stated in the Concept, the "Energy and Raw Materials" scenario is more likely to be achieved as it reflects the current priorities of Russian businesses. However, the "Innovative" scenario is a political goal of the administration of President Medvedev, which assumes the creation of a new business elite as well as more effective government and civil society joining efforts to take a leading position in the world.

All of these three scenarios assume $4 \%$ growth of the world economy; an oil price of \$88 per barrel in 2011, \$97 in 2015, \$116 in 2020 and \$136 in 2025; and a decline in population to 140 million by 2020 . Taking into ac- 
count the high volatility of energy prices, other scenarios for oil prices are also considered, ranging from $\$ 75$ to $\$ 130$ per barrel in 2010 .

Therefore, the range of average economic growth in the period from 2008 to 2020 is $4.6-6.5 \%$ a year, which is larger than the assumed world economic growth (4\%). According to the targeted (“innovative") scenario, Russia will achieve \$30,000 (USD 2005, PPP) level of GDP per capita in 2020 , and $\$ 50,000$ in 2030 - higher than the average per capita income in Europe. The key macroeconomic indicators of the scenarios are presented in the Table 1.2.

Table 1.2. Key economic indicators by scenarios.

\begin{tabular}{lrrr}
\hline & $\begin{array}{r}\text { Inertial } \\
\text { (INT) }\end{array}$ & $\begin{array}{r}\text { Energy and } \\
\text { Raw Materials } \\
\text { (ER\&M) }\end{array}$ & $\begin{array}{r}\text { Innovative } \\
\text { (INN) }\end{array}$ \\
\hline GDP growth: 2020 comparing to 2007 & $180 \%$ & $200 \%$ & $230 \%$ \\
Investment growth: 2020 comparing to 2007 & $240 \%$ & $360 \%$ & $400 \%$ \\
Share of R\&D investments in 2020 & $13,8 \%$ & $14,8 \%$ & $16,5 \%$ \\
Productivity growth 2020 to 2007 & $190 \%$ & $220 \%$ & $250 \%$ \\
Share of Oil and Gas sector in GDP in 2020 & $13,2 \%$ & $12,7 \%$ & $11,1 \%$ \\
Share of Knowledge and High tech economy in GDP in 2020 & $13,3 \%$ & $16,9 \%$ & $17,2 \%$ \\
Poverty in 2020 & $7,9 \%$ & $6,7 \%$ & $6,2 \%$ \\
Middle class in 2020 & $28 \%$ & $47 \%$ & $>50 \%$ \\
\hline
\end{tabular}

Source: Ministry of Economic Development of Russia (2008).

There is also an "Ecological" scenario described briefly in the Concept, which somewhat reflects potential climate and environmental targets. It is considered within the "Innovative" scenario and is characterized by significant demand for environmental improvements. As it states, a target of a 30$50 \%$ reduction in GHG emissions is possible by 2050, and according to the preliminary estimates it would cost $0.3-0.5 \%$ of GDP growth beyond 2020. At the same time higher environmental standards and norms for industries would create new opportunities for economic development (waste recycling, bio-fuels, and "Kyoto forests"). However, the Concept provides neither details of this "Ecological" scenario nor description of how it may be implemented.

Currently, the Russian president and government are focused primarily on the "Innovative" scenario, corrected with the impacts of global crisis. However, for our purposes of modeling and projection of carbon emissions, also other important sources of information and other variables must be considered as described below. 


\subsection{Alternative GDP growth scenarios}

Alternative scenarios for the Russian economy are available from other institutions. In our study we consider two of them prepared by the Russian Institute of Energy Strategy (IES, 2007) and by International Energy Agency (IEA, 2007).

The IES scenarios were designed in the same manner as the MED scenarios ("Inertial", "Energy and Raw Materials", "Innovative") but with a longer-term horizon of projection (up to 2050). The "Innovative” scenario is very close to the MED version while the other two are more conservative.

The IEA scenario is the most conservative in terms of GDP growth assumptions. It assumes average growth of the economy to be $4.3 \%$ per year during the 2005-2015 period, and 2.8\% per annum in 2015-2030. Also, the IEA scenario has more conservative assumptions about the global economic growth for the second period: 3.3\% per year in 2015-2030, compared with $4.2 \%$ a year in $2005-2015$, or $4.8 \%$ and $3.4 \%$ growth per capita respectively. The IEA projection looks more conservative than others and is closer to the "Inertial" scenario by the MED. According to the IEA, Russian GDP will reach almost $\$ 70,000$ per capita (2005, PPP) in 2050, and will be higher than the GDP per capita of France, Germany, United Kingdom and Japan, approaching the per capita GDP of Canada and USA in 2050.

Comparison of GDP growth dynamics in various scenarios is presented in Figure 1.3. We consider all these scenarios with regard to adjustments in the impacts of the on-going global economic crisis, specifically through making the assumptions about GDP dynamics in 2010-2012. For the purposes of our analysis the "Innovative" scenario is used as the baseline for this study so as to be consistent with the target scenario by the Russian government. 


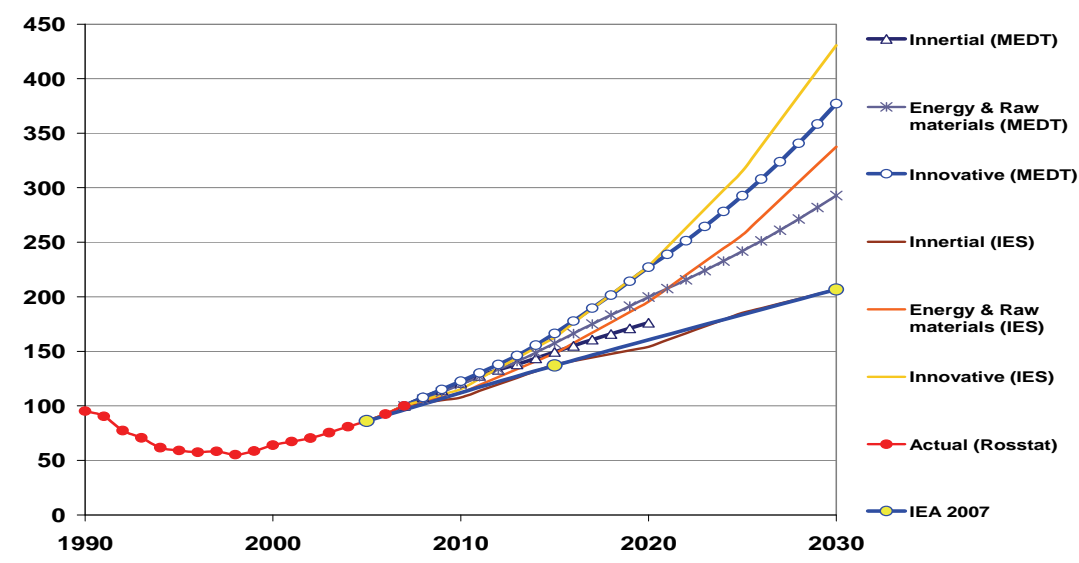

Figure 1.3. Various projections of GDP growth trends.

\subsection{Population trends}

Depopulation trends which started in the beginning of the 1990s will cause a dramatic decline in active population from 89.9 million in 2007 to $77.8 \mathrm{~m}$ in 2020. By 2030 the population may have declined as low as 137 million (143 in 2007). Active demographic policy (financial stimulation of births, migration) could reverse the depopulation trends by 2015 and, as a result, population could reach 144 million in 2020, 145m in 2025 and 146m in 2030. However, the United Nations (UN) scenarios are more pessimistic (Figure 1.4).

In general, the most recent projections tend to be close to constant. Taking into account the recent growth of birth rate in Russia as a result of economic growth, federal programs of family support and positive migration trends in recent years, in our analysis we assume a constant population until 2030. This assumption is consistent with recent population projections by the MED and the UN. 


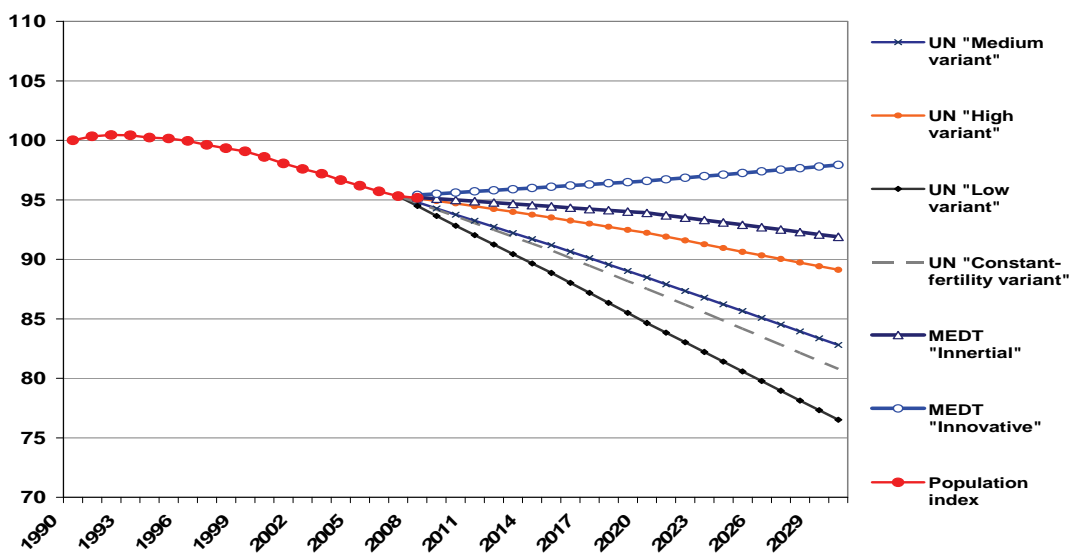

Figure 1.4. Population trends by scenarios in Russia as a percentage of 1990 levels.

Sources: Rosstat; Concept of long-term socio-economic development of Russia by 2030; UN population information network.

\subsection{Energy efficiency potential}

One of the most important potential sources for emissions reductions is improvement in energy efficiency. According to IEA estimates, energy efficiency can account for $40 \%$ of global GHG emission reductions by 2050 (24\% end use fuel efficiency, $12 \%$ end use electricity efficiency, $7 \%$ power generation efficiency and fuel switching) ${ }^{1}$.

Russia's potential for energy efficiency improvement has been estimated by various domestic and international organizations. According to recent estimates by the World Bank together with the Russian Center for Energy Efficiency (CENEF) ${ }^{2}$, Russia can save up to $45 \%$ of its total primary energy consumption if it were to implement a comprehensive reform program. According to their calculations, with the right policy measures Russia could save:

- 240 billion cubic meters of natural gas,

- 340 billion kWh of electricity,

- 89 million tons of coal,

\footnotetext{
${ }^{1}$ IEA (2008), Energy Technology Perspectives 2008 - Scenarios and Strategies to 2050, p.64, Figure 2.2.

${ }^{2}$ WB \& IFC (2008) World Bank \& International Finance Corporation, Energy efficiency in Russia: Untapped Reserves, http://www.ifc.org/ifcext/rsefp.nsf/AttachmentsByTitle/ FINAL_EE_report_Engl.pdf/\$FILE/Final_EE_report_engl.pdf
} 
- 43 million tons of crude oil and petroleum products (measured in crude oil equivalents).

In total, Russia could achieve savings equivalent to all energy produced and imported (net of exports) by France or the UK. Additionally, the Russian economy could benefit from $\$ 120-150$ billion in energy cost savings and increased gas exports annually.

Table 1.3. Technically feasible energy saving potential in Russia until 2020.

\begin{tabular}{lrrrr}
\hline Years & Forecasts of realization of energy saving potential & \multicolumn{2}{c}{ Including electricity saving potential } \\
\cline { 2 - 4 } & Total (millions tce) & $\begin{array}{r}\text { Share of total poten- } \\
\text { tial in 2020, } \%\end{array}$ & TWh & $\begin{array}{r}\text { Share of total } \\
\text { potential in 2020, \%- }\end{array}$ \\
\hline 2010 & $55-58$ & - & $40-43$ & - \\
2015 & $135-140$ & $57 \%$ & $95-100$ & $57 \%$ \\
2020 & $250-275$ & $63 \%$ & $190-200$ & $57 \%$ \\
\hline
\end{tabular}

Source: Energy Forecasting Agency, 2009.

Another study by the Energy Forecasting Agency demonstrated that the overall technically feasible energy saving potential amounts to 250-275 million tons of coal equivalent (tce) by 2020, or 63\% of Russia's total energy efficiency potential estimated as 420 million tons of coal equivalent (see Table 1.3). Figure 1.5 provides recent estimates of energy saving potential until 2020. The data demonstrates that the housing sector, power generation, industries, transport and heat supply constitute $70 \%$ of the total potential.

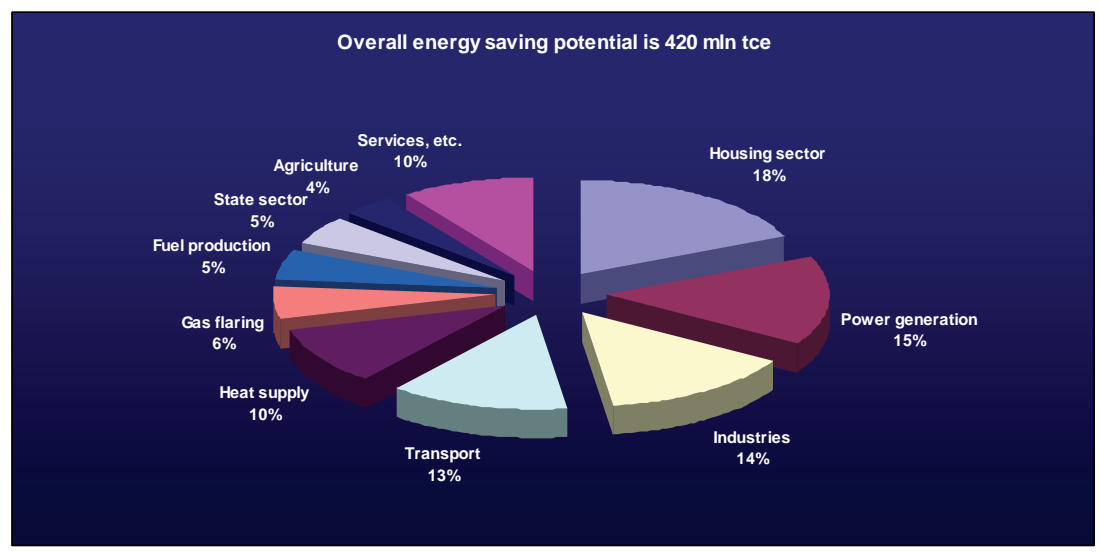

Figure 1.5. Energy saving potential in Russia by sector Source: Energy Forecasting Agency, CENEF, 2009. 


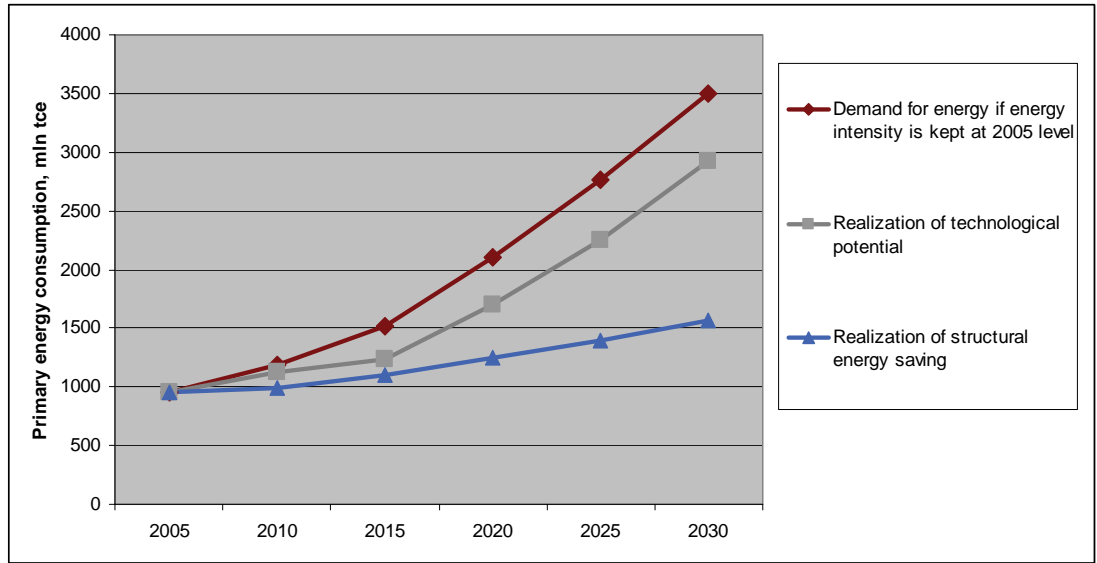

Figure 1.6. Assessment of energy demand and energy savings in Russia Source: Institute of Energy Strategy, 2009.

Figure 1.6 shows the dynamics of energy savings up to 2030, as projected by the Institute of Energy Strategy, a leading provider of analysis to the government and primary author of the new Energy Strategy-2030. According to the Institute's calculations, technological improvements, such as those recommended by the World Bank/CENEF study, in the energy sector would achieve only approximately $25 \%$ of potential energy conservation by 2030 ; the other $75 \%$ would have to be obtained through extensive structural reforms that would increase the share of low-energy intensive sectors, such as services and communications, in the Russian economy. This serves as an indication of the need for a broader energy efficiency policy, one that addresses more than just technological progress in the energy sector.

\subsection{Energy production and export projections}

Development of the energy and raw material sector is a very important part of the long-term strategy of economic development, reflected in the Concept of economic development, Energy Strategy-2030, etc. It can be seen from these documents, that Russia is planning to increase energy and raw materials production and their exports (see Tables 1.3).

There are no detailed projections for coal mining in the Concept. There are only few estimates that coal extraction can increase from 314.5 million tons in 2007 to 400 or 450 to 2020 in "Inertial” and "Innovative" scenarios respec- 
tively. Also some estimates provide fuel mix structure in aggregate energy consumption. Share of coal might increase up to 16.9/18.7/17.8 ("Inertial”/“E\&RM”/“Innovative” respectively) in 2020, and to 18.3/19.1/18.9 in 2030. Therefore coal production in Russia is expected to grow.

The main official document regarding the development of power sector in Russia is the "General schema of allocation of electric power objects" (Genschema) adopted by the Russian government in February 2008. This plan assumed active investment process in the industry and was widely considered as too optimistic. The MED's estimates of electricity demand and projections by scenarios are presented in Tables 1.4 and 1.5.

Table 1.4. Energy resources production and export: projections.

\begin{tabular}{|c|c|c|c|c|c|}
\hline Scenario & 2007 & 2010 & 2015 & 2020 & 2030 \\
\hline \multicolumn{6}{|c|}{ Oil extraction and export (in brackets) projections, millions of cubic meters } \\
\hline Inertial & 491 & $500(256)$ & $500(255)$ & $500(255)$ & $490(245)$ \\
\hline E\&RM & $(258)$ & $514(261)$ & $530(255)$ & $545(255)$ & $540(245)$ \\
\hline Innovative & & $514(261)$ & $530(265)$ & $535(255)$ & $530(245)$ \\
\hline \multicolumn{6}{|c|}{ Natural gas extraction and export (in brackets) projections, millions of cubic meters } \\
\hline Inertial & 651 & $701(216.7)$ & $750(255)$ & $815(287)$ & $880(318)$ \\
\hline E\&RM & $(184)$ & $715(222.7)$ & $825(301)$ & $900(332)$ & $950(328)$ \\
\hline Innovative & & $715(222.7)$ & $800(283)$ & $880(318)$ & $930(318)$ \\
\hline \multicolumn{6}{|c|}{ Electricity generation and consumption (in brackets) projections, millions of KWh } \\
\hline Inertial & 1015 & $1289(1259)$ & $1448(1408)$ & na & $1754(1704)$ \\
\hline E\&RM & $(1002.5)$ & $1437(1380)$ & 1733 (1650) & 2015 (1925) & 2295 (2190) \\
\hline Innovative & & $1400(1365)$ & $1700(1640)$ & $1970(1900)$ & $2230(2150)$ \\
\hline Innovative+Oil & & na (1400) & na (1755) & na (2090) & na (2400) \\
\hline
\end{tabular}

Source: MED, Rosstat

Table 1.5. Shares of electricity production from hydro-, nuclear- and renewable energy under different scenarios (\%)

\begin{tabular}{llrrrr}
\hline Scenario & Source & $\mathbf{2 0 0 7}$ & $\mathbf{2 0 2 0}$ & $\mathbf{2 0 2 5}$ & $\mathbf{2 0 3 0}$ \\
\hline \multirow{2}{*}{ Inertial } & Hydro & 17.6 & 14.2 & na & 13.4 \\
& Nuclear & 15.8 & 20.7 & na & 23.9 \\
E\&RM & Hydro & 17.6 & 15 & 15.5 & 16.9 \\
& Nuclear & 15.8 & 22 & 24.8 & 28.8 \\
\multirow{4}{*}{ Innovative } & Hydro & & & & \\
& Nuclear & 17.6 & 14.4 & 14.5 & 14.8 \\
All & Renewables & 15.8 & 20.6 & 23.4 & 26.9 \\
Innovative & Renewables & 0.5 & $10-20(80.2)$ & $30-40$ & $50-65(120-150)$ \\
& RWear & $0.05(0.9)$ & $0.7-1.4(4.5)$ & $1.5-2$ & $2.2-2.9(6-8)$ \\
\hline
\end{tabular}

*Solar, wind, geothermal, hydrogen, tidal, bio-, etc. (excluding large hydro), EFA's estimates are in brackets. *^Estimated as fraction of projected electricity production of the "Innovative" scenario. 
It may be concluded from review of these projections, that:

- Power consumption in Russia will grow faster than in 2001-2005, but slower than expected in Genschema.

- Dismantling of life-expired, out-of dated generating capacities will be much slower, as well as commissioning of new capacities.

- Growth of coal share in fuel mix consumption structure by power sector will be slower than expected.

- Investment costs are more than double those expected by Genshema.

- Share of investments needed in total investment in the Russian economy is too high to be realistic and government decisions are required.

According to projections by the Energy Forecasting Agency (EFA-2015), demand for power will be lower than expected in Genschema and is close to the MED "Innovative” scenario, high oil prices variant. EFA's "moderate" scenario assumes $5 \%$ less power consumption than "Innovative+Oil" scenario in 2015; the "pessimistic" scenario in 2015 assumes 12\% less demand for power compared to "optimistic" (see Figure 1.7).

Therefore, according to the projections, a range of expected electricity demand is quite large (12\% between low and high projections). This makes it risky to invest in generation capacity. According to the Genschema, generation capacity should grow from 215 GW in 2006 to 287 GW in 2015, which assumes the introduction of $117 \mathrm{GW}$ of new generation capacity. EFA-2015 forecast reduced the projection to 287 with $91 \mathrm{GW}$ of new capacity, and also found that $22 \mathrm{GW}$ of this may not materialize. The main risk factors include low demand, natural gas availability and prices, and independent producers of electricity and heat. 


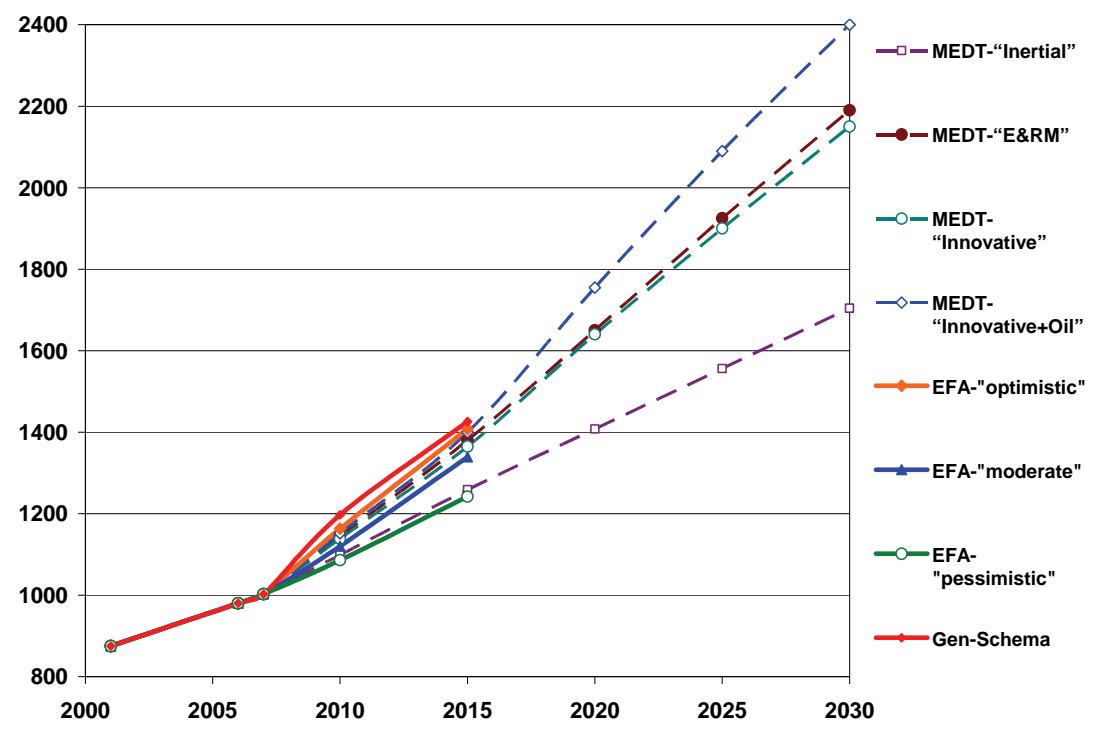

Figure 1.7. Comparison of electricity consumption by MED and EFA scenarios.

\subsection{Emission-related prices and tariffs}

As planned by the government, a new mechanism of natural monopoly pricing will be developed and introduced in 2011-2014. By 2011, 100\% of power prices will be liberalized with government regulation of network tariffs for electricity transmission. Full liberalization of electricity prices for households will be finalized by 2017. The liberalization and liquidation of cross-subsidies will cause significant increase of all tariffs. These policies aim at stimulating modernization, energy saving, and overall efficiency improvement in energy-intensive industries as well as development of modern industries with high value added.

Table 1.6 presents projections of the significant growth of electricity and gas prices, as well as rail transportation and utilities tariffs. Electricity price will double by 2015, and triple by 2015 compared to 2008. Households account for majority of this growth due to structural reforms of the industrial sector. These changes will affect final demand for energy, as well as open more alternative opportunities for both energy production and consumption technologies. 
Table 1.6. Energy and transport tariffs: projections.

\begin{tabular}{|c|c|c|c|c|c|c|}
\hline Scenario & 2007 & 2008 & 2012 & 2015 & 2020 & 2025 \\
\hline \multicolumn{7}{|l|}{ Electricity tariffs, cents per kWh } \\
\hline Inertia & 5.5 & 6.4 & na & 10.2 & 14.3 & na \\
\hline \multirow[t]{3}{*}{ E\&RM \& Innovative } & $(4.5)$ & $(5.1)$ & & $(13-13.2)$ & $(20-21)$ & \\
\hline & & & 9.7 & 11.3 & 14.8 & 17.7 \\
\hline & & & (9.9) & (15) & $(21.6)$ & $(25.7)$ \\
\hline \multicolumn{7}{|c|}{ Heat, Rubles per GCal (2007 prices) } \\
\hline Inertial & 453.0 & 552.7 & na & 1000 & 1300 & $\mathrm{Na}$ \\
\hline E\&RM \& Innovative & & & 906.0 & 1041.9 & 1721.4 & 2038.5 \\
\hline \multicolumn{7}{|c|}{ Gas tariffs for all consumers, US dollars } \\
\hline Inertial & 59.4 & 76.4 & $250-260$ & na & $330-340$ & na \\
\hline & $(43.36)$ & $(54.2)$ & & & & \\
\hline E\&RM Innovative & & & 157 & 262 & 337 & 390 \\
\hline & & & (125) & $(262)$ & $(337)$ & (340) \\
\hline \multicolumn{7}{|c|}{ Rail transport and municipal utilities services for households tariffs growth rate (2007-base year), times } \\
\hline Rail transport (cargo) & & 1.211 & 1.8 & 2.5 & 3.7 & 4.9 \\
\hline Rail transport (passengers) & & 1.14 & 1.6 & 2.1 & 3.0 & 3.8 \\
\hline Utilities & & 1.17 & 2.1 & 3.0 & 4.1 & 5.3 \\
\hline
\end{tabular}

Source: MED, Rosstat

\subsection{Renewable energy potentials for electricity and heat production}

The main renewable energy sources are hydro (large, small, and tidal), wind, solar, geothermal, and bio-fuels. According to Russian legislation, associated gas from coal mining is also considered a renewable energy source.

Hydro power is a significant part of overall electricity generation in Russia (approx. $18 \%{ }^{3}$ ). Also some geothermal plants have been constructed and are currently in use in Russia.

Russia has relatively modest experience with other renewable energy sources, first of all because of abundant reserves of fossil fuels.

A comprehensive study of renewable energy potentials in Russia by Bezrukikh et al (2007) (see Table 1.7) provides estimates for small hydro-, geothermal-, biomass-, wind-, solar-, and low potential heat energy sources in

\footnotetext{
${ }^{3}$ Elektroenergetika Rossii 2030. tselevoe videnie (Electricity Sector of Russia - 2030: Targeted Vision), Eds.B.Vaizinkher. - Moscow, Alpina Business Books, 2008, p. 43.
} 
the Russian regions. There are two types of estimates: technical- and market potentials. The first (technical) estimate refers to the potential that could be taken using existing technologies. The market potential estimates the volume for each energy carrier that could be competitive on the market under the current economic conditions.

Table 1.7. Renewable energy potential for electricity and heat production in Russia.

\begin{tabular}{lll}
\hline & \multicolumn{2}{c}{ Potential } \\
\cline { 2 - 3 } & Technical potential, Mtce & Market potential, Mtce \\
\hline Total in Russia Federation & 24221 & 320 \\
Small hydro (TWh a year) & $126(372)$ & $70(205)$ \\
Tidal & $83(253)$ & - \\
Geothermal & 11868 & 114 \\
Biomass & 140 & 69 \\
Wind (TWh a year) & $2216(6517)$ & $11(33)$ \\
Solar & 9676 & 3 \\
Low potential heat & 194 & 53 \\
\hline
\end{tabular}

Source: Bezrukikh at al, 2007.

Russia consumes almost 1,000 million tons of coal equivalents in gas, oil and coal per year. According to the estimates, around one-third of the consumption could be substituted with economically competitive renewable energy. The technical potential is 25 times higher than the current consumption of fossil fuels.

The economic potential estimates exclude tidal power plants (accounts for some $1 / 4$ of power generation in Russia), and - more importantly - the provided estimates are based on the current economic conditions. Gas and electricity price increases over the next decade will significantly contribute to the competitiveness of renewable energy sources.

The geographical distribution of some renewable resources is shown in Figures 1.8 and 1.9. Evidently, most of the energy sources are located in the areas where only few industrial activities take place at the moment. However, there is still huge potential in the regions with more significant industrial production and population.

Figure 1.10 shows that existing economically viable potential for using renewable energy sources is comparable with the overall production of power and heat in Russia, while the technical potential is much larger. As a result, a significant share of fossil fuels could realistically be substituted with renewables in the near future. 


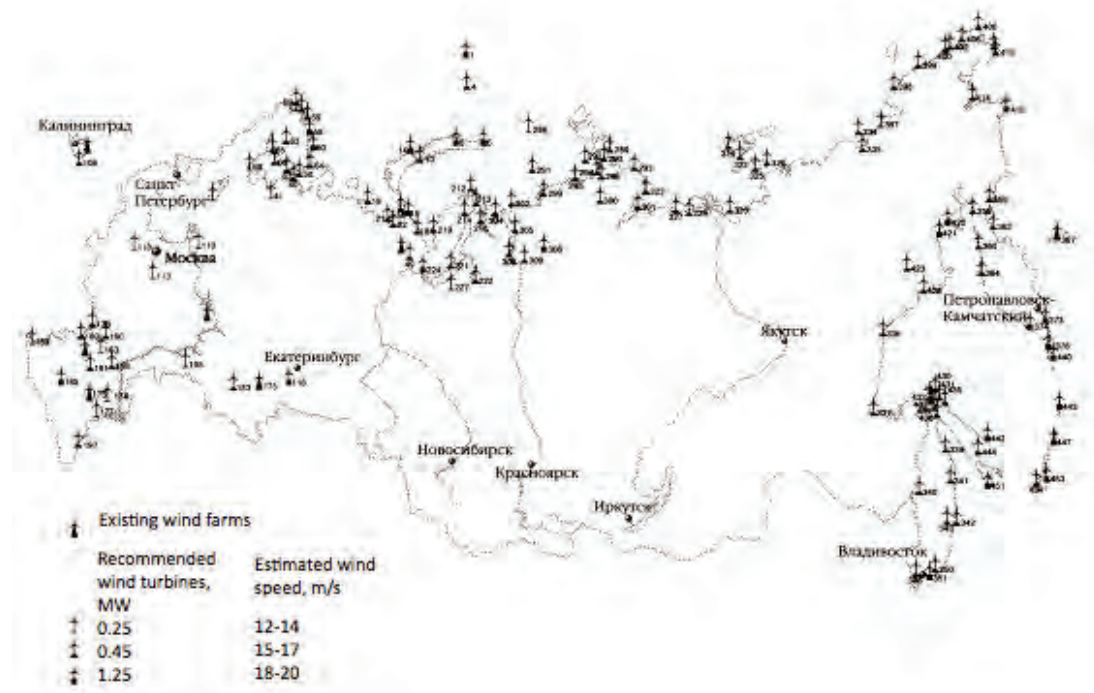

Figure 1.8. Existing and planned wind power plants in Russia.

Source: Estimates of Institute of Energy Strategy, Russian Academy of Engineering, Union of Scientific and Engineering NGO (2007).

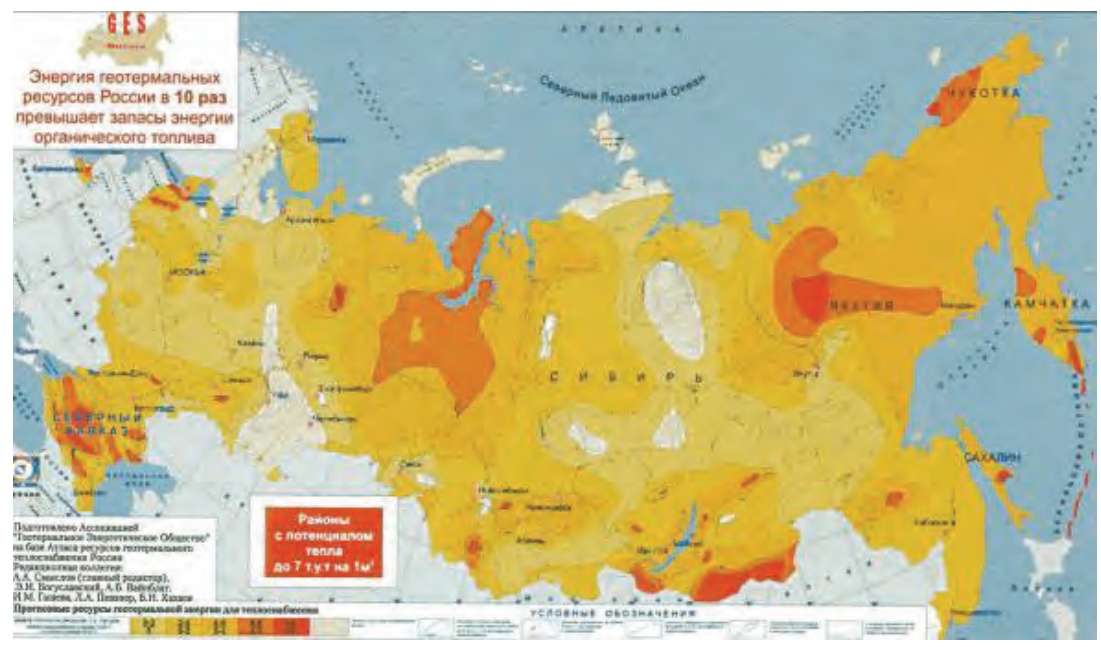

Figure 1.9. Geothermal power resources in Russia.

Source: Russian Association of Geothermal Energy Society. 


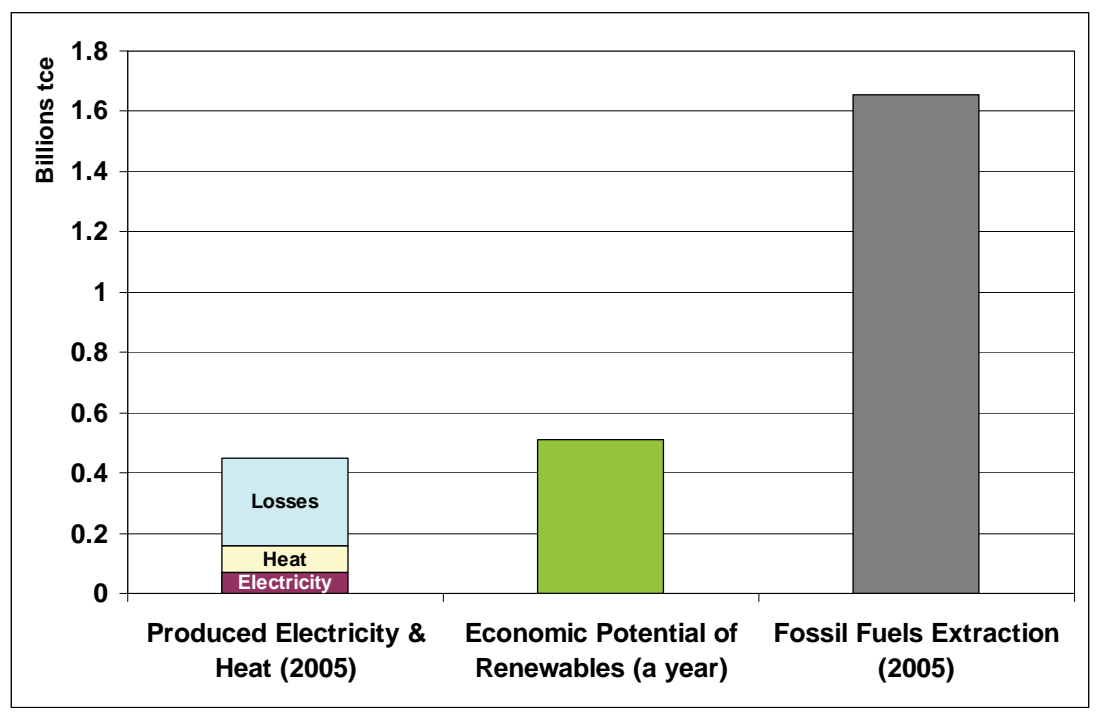

Figure 1.10. Comparison of fossil fuels extraction, production of power and heat and market (commercially viable) potential of renewable sources in Russia.

Source: author's estimates based on Russian statistics and Bezrukih P.P. ed. (2007).

Renewable energy technologies tend to be very efficient in comparison to conventional technologies currently in use in Russia. Pay-back periods of investments in renewable energy technologies can be short, even less than a year; indeed, cost-efficiency of renewables could be much higher than that of conventional fossil fuel based technologies. Mainstreaming of renewable technologies and increasing prices of fossil fuels will contribute to the competitiveness of renewable energy technologies; this will increase the market potential of renewables.

\subsection{GHG emissions projections}

In this paper, two approaches to carbon emission projections were chosen. The first approach is based on the analysis of the historical (1990-2009) data on emissions, economic and other indicators, assumptions about the longterm (2020 and beyond) GDP growth, development industries and sectors of Russian economy, and policy goals.

The second approach is based on applying an advanced RU-TIMES model on emissions in the energy sector, especially on stationary power and 
heat producers. RU-TIMES model allows an in-depth analysis of impacts of different economic and energy policies and measures on the emissions in this sector, and to compare costs and benefits of various post-2012 commitments and policy instruments.

In addition, we consider the findings of the ENERGY-BAL modeling exercise conducted by the CENEF to include some insights on the longerterm emission projections up to 2050.

\section{GHG projections based on historical trends and policy targets}

The historical trends of carbon emission growth over 2000-2007 have been significantly different for various sectors. It can bee seen in Table 1.8 that, despite the high GDP growth in Russia during this period (6-8\% per year) and even higher growth of industrial production (up to $12-14 \%$ per year in some industries), emissions in the main sectors have not been growing especially fast and even declined in some, e.g. 0,4\% per year in energy industries, $0,5 \%$ in solvents and other product use, $-0,2 \%$ in manufacturing and construction, $-1,1 \%$ in agriculture, $-3,5 \%$ in “Other energy sources”). On the other hand, emissions in some sectors have been increasing somewhat, e.g. $5,1 \%$ in transport and ca. 3\% in industrial processes, waste sector and fugitive methane emissions. Emissions from non-specified sources were increasing fast, but their share in total emissions is relatively small (1,5\%).

Russian overall GHG emissions would reach 94\% of 1990 levels if the trends in emission growth would be continued (see Figure 1.11). This assumes that emissions from the sources with negative growth in 2000-2007 would not be declining further on but stabilized at the 2007 level, while the GDP growth would continue to be fairly high by 2020 (6,5\% per annum, as was "planned" in Innovation scenario of MED). However, the financial and economic crisis of 2008-2009 has substantially affected the emission dynamics already and will presumably continue to play an important role in future emission growth.

In the most optimistic scenario, the national carbon emissions would be growing as shown in Figure 1.8 and would reach $79 \%$ of the 1990 level by 2020. This assumes that Russian economy will recover by 2010-2011 and return to high growth (6,5\% per year GDP growth) in 2012 until 2020, continuing the historic trends of 2000-2007,. Of course, if GDP would be grow- 
ing slower than 6,5\% per year, emissions would unlikely reach this level, and stay around $70-75 \%$ as in the case of growth of $4,5 \%$ per year.

On the other hand, in the last one and a half to two years, President Medvedev and the Russian government have dramatically scaled up their priorities in favor of modernization, energy efficiency improvement, technological progress, lowering dependence in oil and gas sector, etc. As a result, it would be unlikely that Russian historical trends of 2000-2007 would continue should the recent political decisions be effectively implemented.

Table 1.8. Historical trends of GHG emissions in Russia by sector in 2000-2007.

\begin{tabular}{lrrr}
\hline & $\begin{array}{r}\text { GHG emis- } \\
\text { sions i } \\
\mathbf{2 0 0 0}\end{array}$ & $\begin{array}{r}\text { GHG emis- } \\
\text { sions in } \\
\mathbf{2 0 0 7},\end{array}$ & $\begin{array}{r}\text { Average } \\
\text { growth of } \\
\text { emissions, \% } \\
\text { per annum }\end{array}$ \\
\hline 1.A.1 Energy Industries & 862056 & 888841 & $+0,4 \%$ \\
1.A.2 Manufacturing Industries and Construction & 115559 & 114023 & $-0,2 \%$ \\
1.A.3 Transport & 152210 & 206450 & $+5,1 \%$ \\
1.A.4 Other Sectors & 182829 & 138459 & $-3,5 \%$ \\
1.A.5 Other (Not elsewhere specified) & 11996 & 33060 & $+25,1 \%$ \\
1.B. Fugitive emissions & 336548 & 404846 & $+2,9 \%$ \\
2 Industrial Processes & 170188 & 208071 & $+3,2 \%$ \\
3 Solvent and Other Product Use & 523 & 541 & $+0,5 \%$ \\
4 Agriculture & 146232 & 134709 & $-1,1 \%$ \\
6 Waste & 52288 & 63818 & $+3,2 \%$ \\
\hline
\end{tabular}

Source: UNFCCC, 2009, estimates by authors.

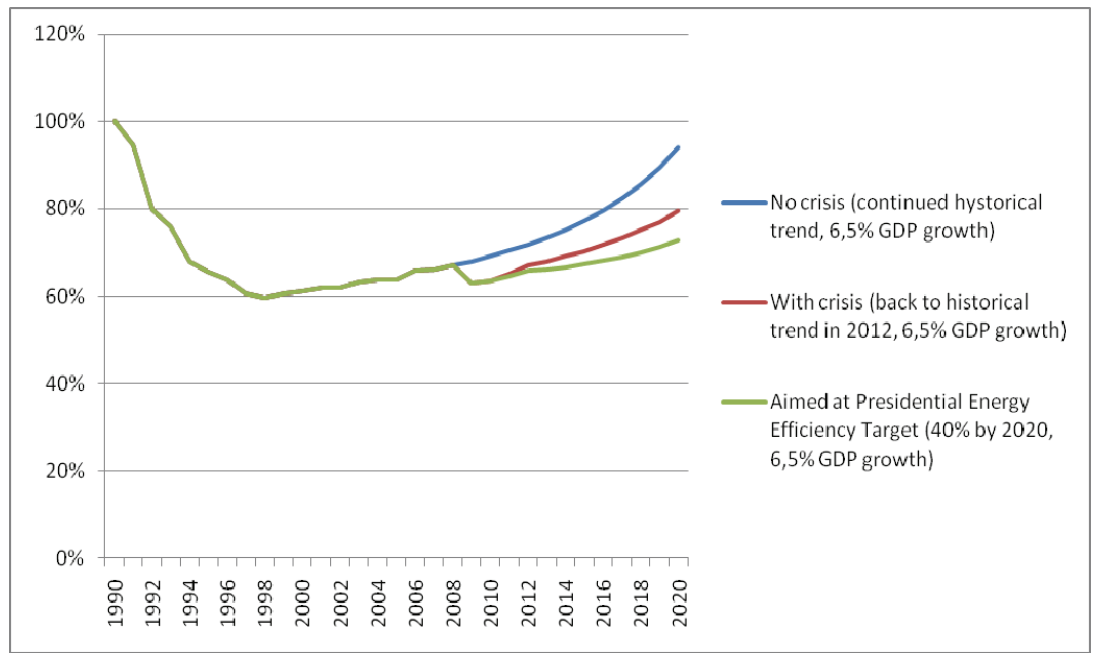

Figure 1.11. GHG emission projections for Russia, 1990=100\%.

Source: UNFCCC; estimates for 2008-2020 by Georgi Safonov, 2009. 
It is difficult to quantitatively estimate the impacts of the policies on modernization, innovation-based development and other measures, so widely used in presidential and governmental rhetoric recently. However, if we only focus on one major target set by President Medvedev in June 2008 of improving energy efficiency of the national economy by at least $40 \%$ by 2020 , we may conclude that Russian emissions would have to reach a maximum of $73 \%$ of 1990 levels by 2020. This implies high economic growth (6,5\% per annum in 2012-2020) and relatively stable energy balance. A stable energy balance is a reasonable assumption in our view, as there are no indications of huge growth of coal consumption in the country in the last decade, expected moderate growth of nuclear power and hydro power generation, and even continuing gasification of Russian cities and villages.

In the case of lower GDP growth, for instance 3-4\% per annum, the Presidential target would require energy consumption to decline in absolute terms rather than grow. As a result GHG emissions would unlikely exceed $65 \%$ of that of 1990 levels by 2020 .

Here we do not consider impacts of other decisions, such as the governmental decree on increase of renewables" share in energy balance from less than $1 \%$ to $4,5 \%$ by 2020 . This may have a marginal impact on national emissions in the near term, but may play a substantial role in longer-term renewable energy policy though learning-by-doing, supporting technologies, etc.

After all, the main conclusion regarding Russia's commitments on post2012 and domestic mitigation policies and measures is that the first Russian proposal of $-10 \% /-15 \%$ of 1990 levels was a weak commitment, which can be easily fulfilled. The level of $-20 \%$ is possible to reach by merely continuing the recent trends in sectoral development. But active policy in energy efficiency, modernization, innovation spheres would likely lead to emission stabilization at -27-35\% of 1990 levels by 2020 .

\section{$R U$-TIMES : modeling of emissions in energy sector}

After the macro-view on Russian emission trends and impacts of policies and measures on overall emissions, one of the major sources of national emissions, the large stationary energy producers (power plants and boiler houses), is considered in-depth.

For this purpose we use RU-TIMES model (a new version of the well known MARKAL model aimed at the economy-energy-environment model- 
ing). ${ }^{4}$ The RU-TIMES model focuses on the largest share of Russian energy sector. In Russia, energy production and consumption are the main contributors to total GHG emissions. All fossil fuel combustion contributes about $60 \%$ of total GHG emissions $(1.12,1.13,1.14)$. The modeled part of energy sector includes main activity electricity and heat producers, other independent producers, such as power plants, large energy units of industrial plants and large and medium-sized boiler houses. In total, the model covers over $50 \%$ of $\mathrm{CO}_{2}$ emissions from fossil fuel combustion in this sector.

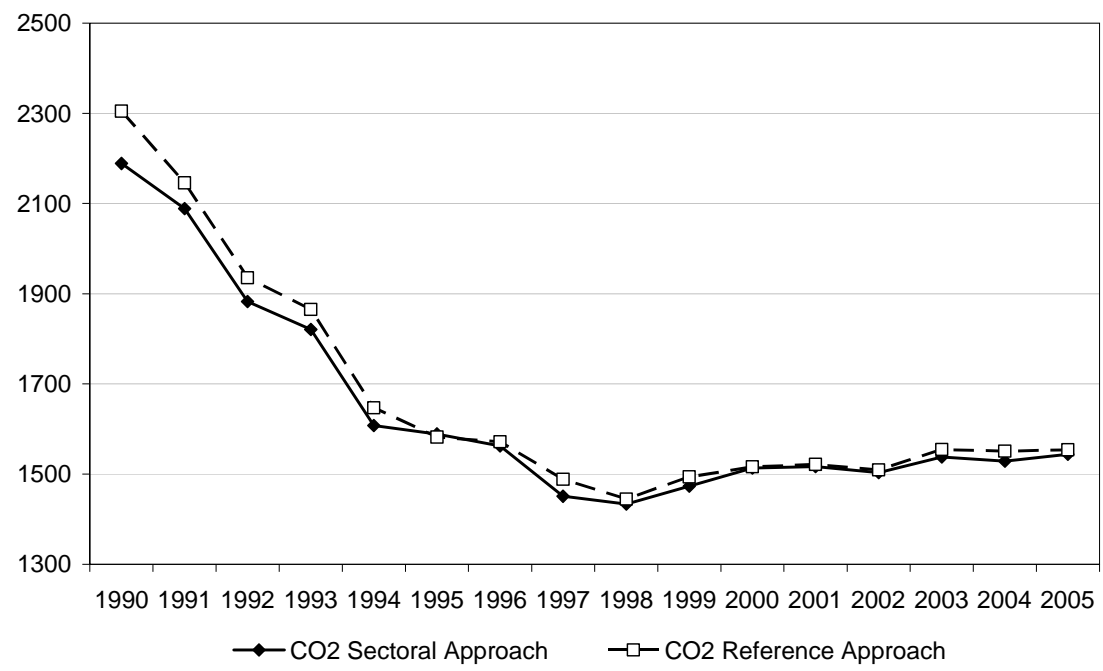

Figure 1.12. $\mathrm{CO}_{2}$ emissions trends from fuel combustion in Russia. Source: IEA.

\footnotetext{
${ }^{4}$ This Russian TIMES model has been developed by Dr. Oleg Lugovoy (Institute of Transitional Economy/ Environmental Defense Fund) and calibrated on the latest Russian data on economic development, technological features, energy sector development, pollution characteristics, etc. (Brief overview of the TIMES model is presented in Annex 1.)
} 


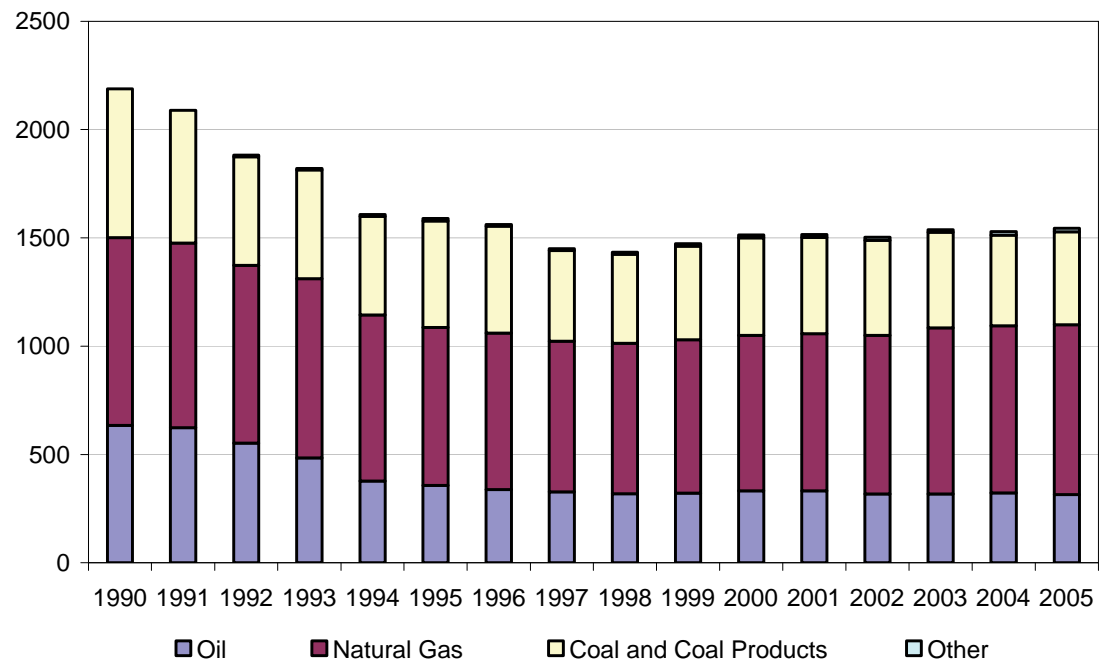

Figure 1.13. $\mathrm{CO}_{2}$ emissions from fuel combustion in Russia Source: IEA.

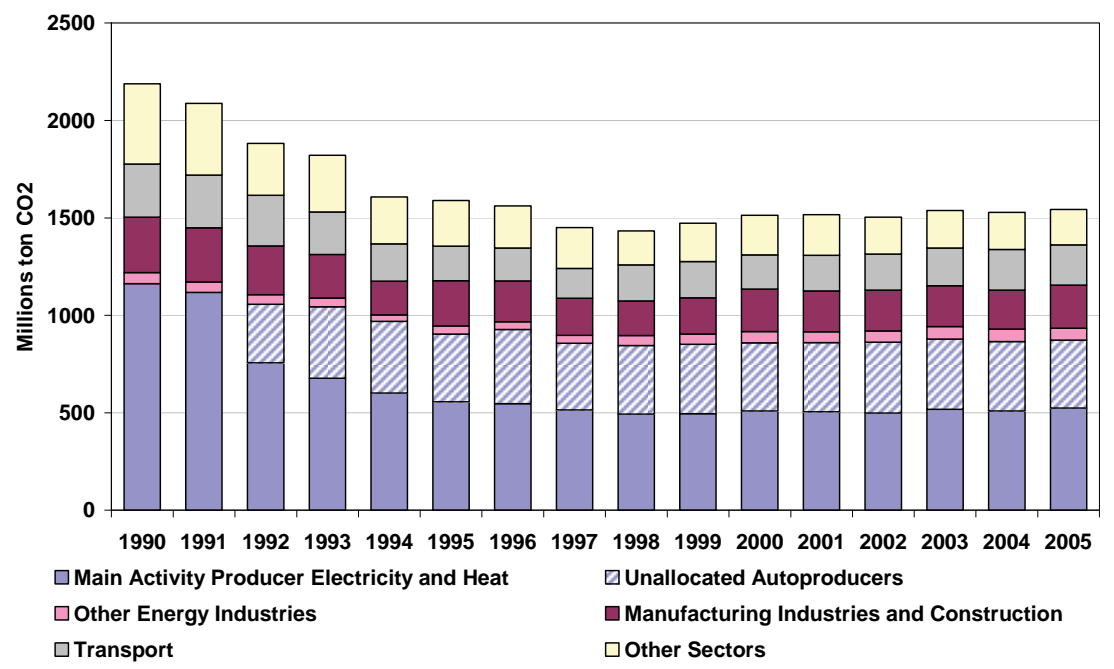

Figure 1.14. $\mathrm{CO}_{2}$ emissions by economic activity in Russia Source: IEA.

The following assumptions were made for the RU-TIMES model:

Demand for electricity and heat. The MED projections provided in the Concept are used together with EFA scenarios of electricity generation. As it 
was mentioned above, electricity demand scenarios vary from 1242 to 1408 TWh in 2015 (projections by Genschema are not considered because the projections were updated by the Energy Forecasting Agency - EFA with three scenarios). Three MED scenarios are taken into consideration: "Innovative” (Inn), "Energy \& Raw Materials” (ENR), and "Inertial” (INT). The "Innovative" scenario with no special climate or energy policy (not stated in the Concept) is also considered as reference (REF). This is the most important cluster of assumptions in the Scenario.

Heat: The MED's Concept provides no estimates on heat. The main consumers for heat include industry and households. Here it is assumed that demand for heat by the industrial consumers depends on GDP with elasticity 0.1 and by other sectors (including residential and commercial sectors) and on population with constant elasticity. Taking into account the massive inefficiency of Russian buildings and heating, these assumptions look conservative; therefore, no significant improvements in buildings heat efficiency are at sight.

Renewable energy potentials for electricity and heat production. According to the estimates introduced above, the renewable energy potential of Russia is significant. Recent experiences and investment profitability assessments show short pay-back periods and high rates of return on investments in renewable energy technologies. However, the speed of the mainstreaming of these new technologies depends on various issues including the availability of financial resources, time of construction, and economic and political incentives to develop renewable energy use. According to the MED projections, renewables will reach 10-20 TWh a year (0.7-1.4\% excluding large hydro). These estimates can be considered very modest and fail to fulfill the goals of the "Innovative" scenario. EFA's goals (4.5\% to 2020) are much higher but less aggressive; EFA's estimate is used as a baseline. In addition, total resource constraints to each renewable energy source on the "economic potential" level are applied $^{5}$ i.e. total renewable energy resource is considered as the equivalent to the economic potential in the period up to 2030.

MED long-term projections. Long-term projections of socio-economic indicators were taken from the Concept of long-term socio-economic development (MED): GDP growth and population trends (as drivers for the heat demand), large hydro- and nuclear power plants shares in total electricity consumption (with the assumption of 2-3\% change by bounds in 2020),

\footnotetext{
${ }^{5}$ Bezrukikh (2007).
} 
international oil prices, gas tariffs, annual potential of fossil fuels extraction and export (with total available reserves limits).

Crisis scenarios. Also some crisis scenarios with various assumptions regarding recession and recovering growth are considered. A 9\% drop of GDP is assumed in 2009 with 1-2\% growth rate in $2010-1011$ and $4.5 \%$ growth rate in 2012 and on (Figure 1.15).

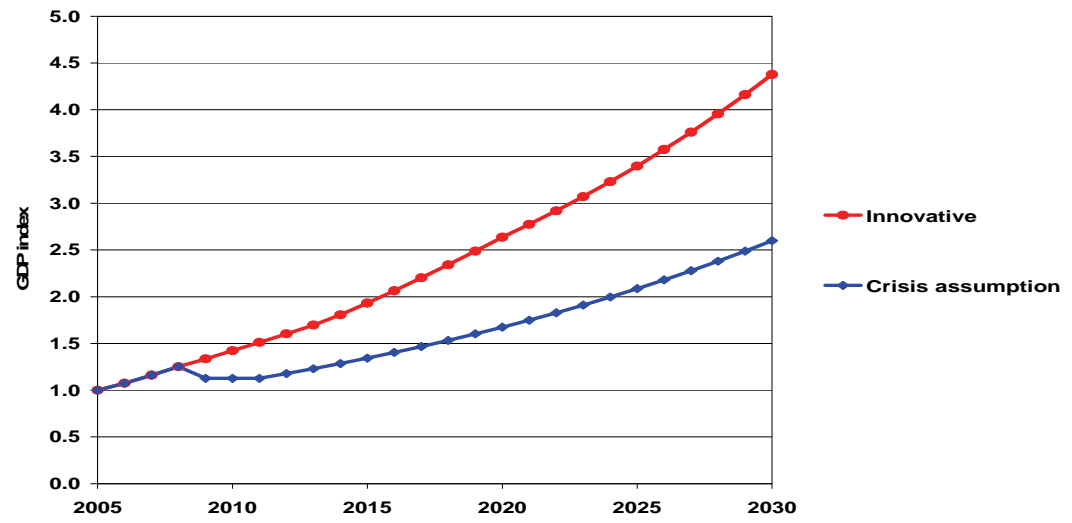

Figure 1.15. GDP growth assumptions: with and without crisis.

Other assumptions. There are some other assumptions required for the analysis. A $30-40 \%$ (2-2.7\% a year) renewal of the current capacities of fossil fuels electricity and heat plants (gas, coal and oil products power and heat plants) is assumed. As a result, some $60-70 \%$ of the current capacity stock will not be upgraded with the new and more efficient equipment. We assume that internationally traded emissions permission prices will be $10 €$ per ton $\mathrm{CO}_{2}$ in 2012, 20€/ton in 2020 and 25€/ton in 2030. A case of Russia joining the international carbon market in 2012 is considered. Another important assumption relates to the costs of introducing new technology (the model is cost-optimizing). The capital costs, maintenance and operating costs vary significantly among technologies, countries and particular projects, so we had to make assumptions about the costs using the average values (mainly, from IEA), when we had no Russian estimates.

\section{$R U$-TIMES findings}

According to the RU-TIMES model, $\mathrm{CO}_{2}$ emissions in the power and heat sector in Russia will grow until 2020 in the most ambitious scenarios, and 
will decrease after 2020 (Figure 1.16). In the most optimistic cases of energy demand growth emissions will never reach 1990 levels by 2020 in the sector.

There are a few factors behind the relatively slow growth of emissions:

- The share of nuclear production in Russia as stated in the MED's concept of long-term development.

- The share of renewable energy sources in electricity and heat production. According to the MED projections, gas and electricity tariffs will multiple by 2020. This will contribute to the competitiveness of renewable energy sources in comparison to conventional fossil-fuels combustion technologies. The limiting factors for switching to renewable include existing stock of capacities (only 30\% of existing capacities is assumed to be upgraded with new, more efficient equipment or dismantled by 2020).

- The speed of modernization and commissioning new capacity construction: an average rate of not more than $5 \%$ annually is assumed.

The fuel mix structures of electricity production for the reference scenario in absolute and relative terms are presented in figures 1.17 and 1.18. They show that by 2030 the share of nuclear power is expected to increase, the shares of renewables and coal are expected to remain fairly constant, while the shares of oil and gas will decline.

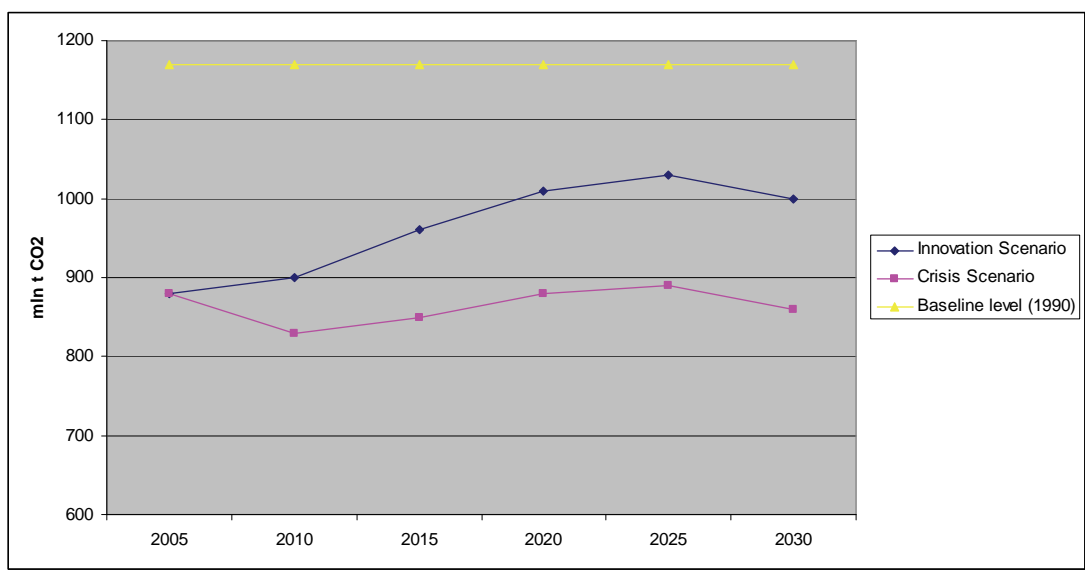

Figure 1.16. $\mathrm{CO}_{2}$ emission projections based on RU-TIMES model. 


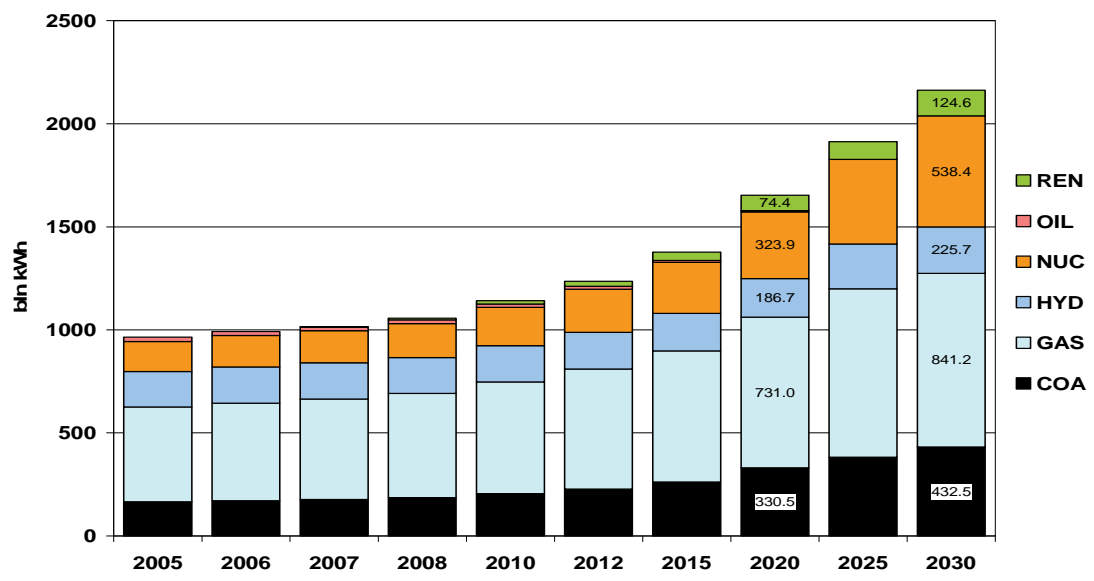

Figure 1.17. Electricity generation by fuels, "Innovative” scenario (Reference), billions $k W h$.

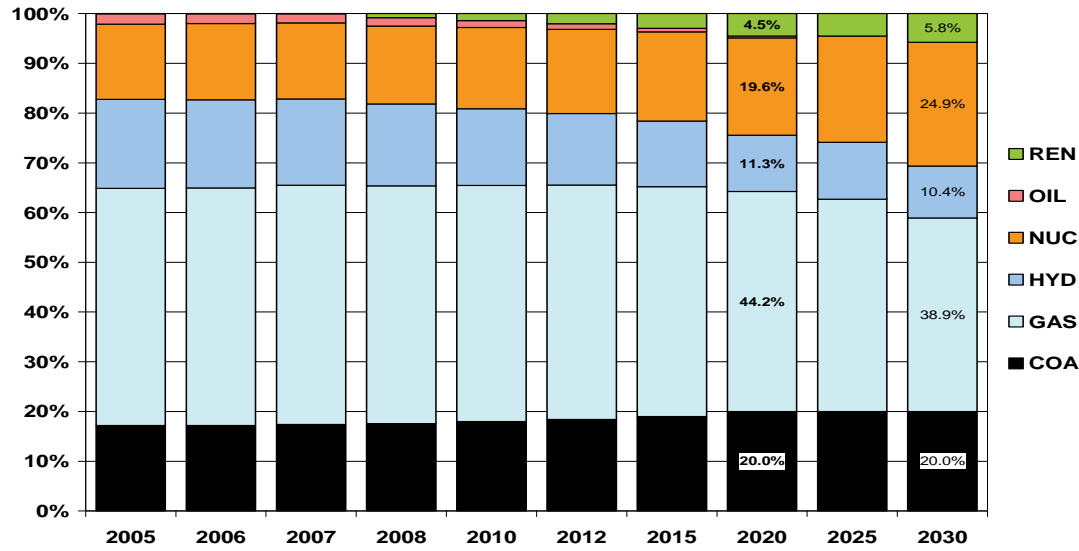

Figure 1.18. Electricity generation by fuels, "Innovative” scenario (Reference), \% shares.

In this study we have also modeled and analyzed a range of scenarios related to various assumptions of economic development (e.g. slower recovery from global economic crisis), policies and measures to control emissions (e.g. setting limits on $\mathrm{CO}_{2}$ emissions at different levels below 2008 level, imposing taxes on $\mathrm{CO}_{2}$ emissions), etc.

Against the widespread belief that Russia's carbon emissions will continue to grow in tandem with GDP growth, the model illustrates that a num- 
ber of scenarios show declining emission trends until 2020 and 2030 in the electricity sector. Some scenarios (with strict caps on $\mathrm{CO}_{2}$ emissions at 2008 level and links to the global carbon market that would allow for domestic companies to capitalize on $\mathrm{CO}_{2}$ emission reduction via direct sale of allowances) show a decline of sectoral emissions even by 25\% below 2008 level by 2020 (approximately 50\% below 1990 level) and 30\% by 2030 (some 54\% below 1990 level). In such scenarios we clearly saw that there are pathways for decoupling GDP and GHG emission growth rates applying the regulatory frameworks that provide wide-scale incentives and market opportunities for electricity companies reducing $\mathrm{CO}_{2}$ emissions.

To large extent, these pathways relate to the utilization of the huge potential of renewable energy sources available for electricity and heat production. Their economic potential accounts for about a third of the current fossil fuels consumption in Russia (excluding large hydro), while the current contribution of the renewables to electricity production remains below $1 \%$.

According to the IEA estimates, energy efficiency can contribute up to $40 \%$ of global GHG emissions reductions by 2050 . Recent World Bank \& IFC estimates show that Russia can save up to $40 \%$ of currently consumed energy by implementation of existing technologies. This is a major opportunity to reduce emissions and could significantly decrease demand for electricity and heat.

Also, some other factors are relevant to slowing growth or declining Russian GHG emissions. For instance, the increasing share of nuclear power production in Russia as stated in the MED's concept of long run development can contribute.

The RU-TIMES model shows that effective use of the potentials provided by renewable energies, nuclear energy as well as modernization policies boosting the currently slow capital cycle allows Russia to follow a lowcarbon development pathway. Regardless of the global economic crisis, Russia can undertake lots of measures aimed at GHG emission reduction. However, the crisis established a significant barrier to Russian enterprises in the form of a lack of financial resources for investments. Therefore, it is extremely important to link Russia to the global carbon market to provide these resources. 



\section{Section 2. Implications of the Russian participation for the Future Climate Regime}

Author:

Dr. Anna Korppoo, the Finnish Institute of International Affairs 



\section{The Elements Relevant to the Comparability of the Russian Pledge}

This chapter is divided into three sections: depth of the Russian pledge, carry-over of the surplus and the impact of forest sinks to the commitments for Russia.

\subsection{The Russian pledge}

The evolution of the Russian emission limitation pledge for the future climate regime since summer 2009 has been intriguing. In June 2009 Russian President Dmitry Medvedev announced a 2020 emissions reduction target of $10-15 \%$ below 1990 levels. $^{6}$ In the EU-Russia Summit in Stockholm in November 2009, he pledged a deeper target of $22-25 \%$ over the same pe$\operatorname{riod}^{7}$; in Copenhagen, the negotiation process never reached bargaining emission reduction commitments due to fundamental differences between the developed and developing country groups. After the Copenhagen summit, the UNFCCC Secretariat invited pledges under the Copenhagen Accord by the end of January 2010. In this occasion, the Russian government took a step back offering a 15-25\% limitation only ${ }^{8}$. Further, president Medvedev confirmed the Russian commitment to be 25\% below 1990 level in February

\footnotetext{
6 “Conversation between Dmitry Medvedev and Director of News Programmes at Russia's Channel One, Kirill Kleimenov”. Available at http://www.kremlin.ru/eng/speeches/2009/06/18/ 1241_type82916_218210.shtml. Accessed 10 March 2010.

${ }^{7}$ President of Russia, Пресс-конференция по итогам 24-го саммита Россия-EC. Available at http://news.kremlin.ru/transcripts/6034. Accessed 10 March 2010.

${ }^{8}$ Russian submission to the UNFCCC, 29 January 2010. Available at http://unfccc.int/ files/meetings/application/pdf/russiacphaccord_app1.pdf. Accessed 10 March 2010.
} 
$2010 .^{9}$ In this study, however, the officially submitted range of $15-25 \%$ emission limitation is used.

Figure 1 outlines the development of the main energy and carbon indicators of the Russian economy. It illustrates the impact of the economic transition after 1990, which is both the year of comparison under the Kyoto Protocol and Russia's commitment. The significant difference between Russia's commitment and the level of real emissions (34\% below 1990 level in 2006) suggests a large potential to commit to a considerably deeper emission limitation beyond 2012.

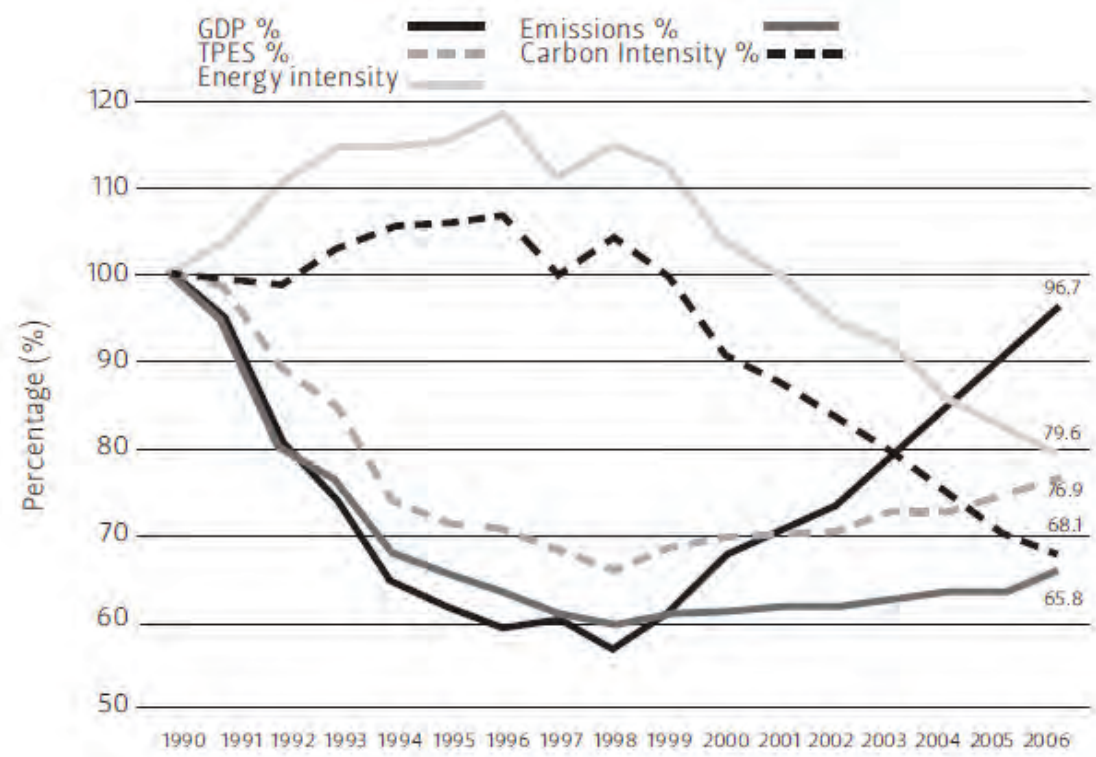

Figure 1. Trends in Russian energy and emissions.

Source: Korppoo, Anna; Jakobson, Linda; Urpelainen, Johannes; Vihma, Antto and Luta, Alex (2009). Towards a new climate regime? Views of China, India, Japan, Russia and the United States on the road to Copenhagen. FIIA report 19, the Finnish Institute of International Affairs.

Figure 1 provides evidence that the emissions have started decoupling from the GDP in the end of the 1990s, however, the emission trend has been growing slowly but steadily over most of the 2000s. Even though the structural shift of the economy from heavy industry towards the service sector

\footnotetext{
${ }^{9}$ Medvedev, Dmitry. Opening remarks at meeting on climate change, 18 February 2010. Available at http://eng.kremlin.ru/text/speeches/2010/02/18/1841_type82913_224384.shtml. Accessed 10 March 2010.
} 
explains some of this, the decoupling of the emission from the GDP was to a large extent delivered by the dramatic increase of the value of the GDP as a result of the peaking oil prices in the 2000s. Depending on the estimate and method, the energy sector accounts for $20-30 \%$ of the Russian GDP ${ }^{10}$.

It remains unclear which assumptions the analysis arriving to the original $10 \% /-15 \%$ pledge was based on. An annual emissions growth of $2.2 \%$ to 2020 , double that of the boom years 2000-2007, could reach roughly $15 \%$ below 1990 levels by 2020. Mathematically, it is possible to conduct such an exercise by either strongly undermining or altogether ignoring the impact of the economic crisis, assuming strong GDP growth around 6.5\% per annum, and excluding the impact of the existing energy efficiency policies to GHG emissions. A more realistic 1\% annual emissions growth from 2012 to 2020, in line with the $1.1 \%$ seen 2000-2007, indicates that Russia's emissions would be $25 \%$ below 1990 levels, which corresponds to the current lower pledge.

However, when estimating emission limitation potential based on GDP projections, the GDP growth factors should be further scrutinized. Beyond the high oil price, the explaining factors behind the rapid economic growth (6.9\% on average) over 2000-2008 included the existing under-utilized production capacity, which could be brought online without large investments, as well as the structural shift of the economy towards the service sector and the middle class consuming these services. These elements can no longer provide additional growth; the existing production capacity was in almost full use in 2008, and under the current economic circumstances it will be difficult to attract investments required for modernizing the economy and increasing production capacity. As a result, Russia's growth potential ${ }^{11}$ is widely believed to be some $4-5 \%$ per annum ${ }^{12}$.

Figure 1 illustrates how the GHG trend decoupled from the booming oil price based GDP growth in the 2000s. This suggests that high oil price based GDP growth in Russia does not lead to skyrocketing emissions. As a result, it could be argued that when estimating the potential to limit emissions, the

\footnotetext{
${ }^{10}$ Suni, Paavo (2007). Oil Prices and the Russian Economy: Some Simulation Studies with NiGEM, p.3.

${ }^{11}$ Growth potential consists of elements such as capital, labour, structural change and technical development.

${ }^{12}$ Deutsche Bank Research, Russia in the Financial Crisis and Beyond. 11 December 2009. p.12. Sutela, Pekka, Venäjä tuskin toipuu nopeasti at Venäjä ja kansainvälinen rahoituskriisi. BOFIT Online 2/2009.
} 
Russian government should separate the impact of the oil price to GDP growth in order to arrive in a rigorous conclusion.

It is easy to conclude that the Russian pledge is far from comparable to the pledges of the majority of Annex I. According den Elzen et al. (2009, p. 63), the comparable effort by Russia in sharing an aggregate 30\% reduction of emissions between the Annex I would be a 50\% reduction of the 1990 level by $2020^{13}$. Even though a comparison of the pledges as such provides little information of the comparability of effort, Table 2.1 outlines the emission trends indicated by the Annex I pledges during 2007-2020, and a set of rough carbon intensity indicators of the economies $\left(\mathrm{CO}_{2} / \mathrm{GDP}\right)$. It is striking that the Annex I transition economy members with the least ambitious pledges are also the most carbon intensive economies. This can be explained by the Soviet legacy of inefficient heavy industry and systemic problems with the newly-established market economies which lead to the lack of incentives to save resources.

Table 2.1 Comparison of Annex I emission trends and carbon intensities.

\begin{tabular}{lllr}
\hline Country & Pledge below 1990 & $\begin{array}{l}\text { Change of emissions } \\
\mathbf{2 0 0 7 - 2 0 2 0}\end{array}$ & $\begin{array}{r}\mathbf{C O}_{2} / \mathbf{G D P} \text { (kt of } \mathbf{C O}_{2} \\
\text { per million 2000 PPP } \\
\text { US\$) in 2004 }\end{array}$ \\
\hline Australia & $11 \% /+13 \%$ & $-31 \% /-13 \%$ & 0.58 \\
Belarus & $5-10 \%$ & $+45 \% /+53 \%$ & 1.03 \\
Canada & $+2.5 \%$ & $-19 \%$ & 0.69 \\
European Union & $20-30 \%$ & $-12 \% /-23 \%$ & $\mathrm{~N} / \mathrm{A}$ \\
Japan & $25 \%$ & $-31 \%$ & 0.36 \\
New Zealand & $10-20 \%$ & $-26 \% /-35 \%$ & 0.35 \\
Norway & $40 \%$ & $-46 \%$ & 0.53 \\
Russia & $15-25 \%$ & $+29 \% /+14 \%$ & 1.17 \\
Switzerland & $20-30 \%$ & $-18 \% /-28 \%$ & 0.17 \\
Ukraine & $20 \%$ & $+70 \%$ & 1.18 \\
United States & $3.5 \%$ & $-17 \%$ & 0.56 \\
\hline
\end{tabular}

Sources: The Human Development Index 2007/2008; Joint submission by Australia, Belarus, Canada, Croatia, the European Community and its Member States, Iceland, Japan, Kazakhstan, Liechtenstein, Monaco, New Zealand, Norway, Russian Federation, Switzerland, Ukraine to AWG-LCA and AWG-KP, 9 October 2009.

\footnotetext{
${ }^{13}$ den Elzen, Michel et al. "Pledges and Actions: A scenario analysis of mitigation costs and carbon market impacts for developed and developing countries”, The Netherlands Environmental Assessment Agency, 2009. WAB 500102032.
} 


\subsection{Carry-over of the Russian surplus}

The dramatic post-1990 restructuring of the Russian economy came with economic, social and political hardship and upheaval, as well as led to a collapse in Russia's emissions. In 2007, Russian greenhouse gas emissions were $34 \%$ below the Kyoto base year 1990 level. If not sold on the international carbon market, the surplus emissions allowances could be banked to be used during the second Kyoto commitment period beyond 2012. However, it remains unclear whether the Kyoto Protocol will be the legal instrument to establish the post-2012 climate regime. Even in the case of a separate legal instrument, the surplus - or some of it - could potentially be carried over to the next agreement depending on the negotiations. The feeling of entitlement to the surplus as a compensation due to the economic transition related hardship is felt in Moscow, regardless of the legal format of the follow-up agreement. However, the Russian position on the carry-over remains unclear. According to Alexander Bedritsky, an adviser to president Medvedev, Russia will endorse a global deal only if it is allowed to transfer its permits ${ }^{14}$ while the view of the Kremlin sherpa Arkady Dvorkovich is that as Russia would like to abandon the Kyoto Protocol, there is nothing to carry over. $^{15}$

The size of the Russian surplus remains unclear as the first commitment period is under way, and even the first year 2008 cannot be fully analyzed yet as the official emission data is still unavailable. Whereas in 2008, international estimates of Russia's surplus of AAUs for the period 2008-2012 were at the range of 3,3-4 $\mathrm{Gt}^{16}$, updated 2009 figures suggested a surplus of 3.5-5 Gt $\mathrm{CO}_{2} \mathrm{e}^{17}$. In 2009, the Russian GDP fell by $7.9 \%$ compared to $2008^{18}$ and industrial production fell by $10.8 \%$ respectively. ${ }^{19}$ As a result, the size of the surplus could be much larger; according to den Elzen et al.,

\footnotetext{
${ }^{14}$ Wall Street Journal Online, 14 December 2009, Russia Demands Its Credits.

${ }^{15}$ Interfax, 8 December 2009. Roadmap of further talks to be adopted at Copenhagen climate conference - Dvorkovich.

${ }^{16}$ Laing, Tim; Junankar, Sudhir, Pollitt, Hector and Grubb, Michael, Global Carbon Mechanisms Annex II: Emissions and demand projections to 2020. Climate Strategies, March 2009.

${ }^{17}$ World Bank 2009, Quoted in Mark Larzarowicz, “Global Carbon Trading: A framework for reducing emissions”, United Kingdom Department of Climate Change, June 2009, pp. 19.

${ }^{18}$ Rostat (2010). Национальные счета: валовой внутренний продукт. Available at http://www.gks.ru/free_doc/new_site/vvp/tab3.xls. Accessed 080310.

${ }^{19}$ BOFIT Venäjätilastot 5 March 2010. Available at http://www.bof.fi/bofit/seuranta/ venajatilastot/. Accessed 18 March 2010.
} 
Russia's share would be at least $7 \mathrm{Gt} .{ }^{20}$ Based on this and the scenarios presented in Figure 1.11 in Section 1, the size of the Russian surplus would be at the range of 5-7 Gt.

The rough impact of the Russian surplus on the Annex I targets, depending on the size of the surplus, is outlined in Table 2.2. Two sets of targets, the IPCC range target 25-40\% reduction of 1990 level by 2020, and the current level of pledges (high and low ranges) by Annex I (based on the 31 January 2010 submissions under the Copenhagen Accord) which would only deliver a reduction of $12-19 \%$ of 1990 level by $2020^{21}$, were used. The impact would be a weakening of the IPCC-recommended target by $9-14 \%$ in the case of $5.1 \mathrm{Gt}$ of surplus, $10-16 \%$ in the case of a 5.9 Gt surplus, and $12-19 \%$ in the case of 7 Gt surplus. Impact of the surplus on the current Annex I pledges would be more significant: roughly $20-40 \%$ of the expected reduction, depending on the size of the surplus and the depth of the target. Such watering down of the commitment, should the surplus replace domestic action in other Annex I countries, is very significant.

Table 2.2 Share of the Russian surplus of Annex I targets: the IPCC range, and the upper and lower Annex I pledge as of 31 January 2010

\begin{tabular}{lcrrr}
\hline & Annex I target & $\mathbf{5 . 1}$ Gt & $\mathbf{5 . 9} \mathbf{~ G t}$ & $\mathbf{7 ~ G t}$ \\
\hline The IPCC range pledges & $-25 \%$ & $14 \%$ & $16 \%$ & $19 \%$ \\
& $-40 \%$ & $9 \%$ & $10 \%$ & $12 \%$ \\
Total of the current pledges & $-12 \%$ & $28 \%$ & $33 \%$ & $39 \%$ \\
& $-19 \%$ & $18 \%$ & $21 \%$ & $24 \%$ \\
\hline
\end{tabular}

Source of data: www.unfccc.int, impact on pledges if the surplus is divided evenly over an assumed 2013-2020 commitment period.

\subsection{Forests as carbon sinks}

Accounting rules for the land-use, land-use change and forestry (LULUCF) sector, in particular for forest management, are currently under discussion in the UNFCCC negotiations; the focus is on setting reference levels for forest management against which to measure annual sequestrations and emis-

\footnotetext{
${ }^{20}$ The Netherlands Environmental Assessment Agency estimates the first commitment period surplus at $13 \mathrm{Gt} \mathrm{CO}_{2} \mathrm{e}$, whereas the Commission places the estimate at $10 \mathrm{Gt}_{2}$. The range arises from uncertainties as to the impact of the economic crisis on emissions, and the expected recovery of economic activity to 2012.

${ }^{21}$ Levin, Kelly \& Bradley, Rob (2010). Comparability of Annex I Emission Reduction Pledges. The World Resources Institute Working Paper, February 2010.
} 
sions. $^{22}$ Countries have inscribed provisional reference levels for forest management into an Annex to the current negotiating document. ${ }^{23}$

Russia's submission on LULUCF from 30 October 2009 outlines the effect of different accounting rules on its assigned amount. Assuming net-net accounting with different reference periods ${ }^{24}$ and no cap or discount on removals, Russia could potentially gain a large windfall of credits, as a result of the high uncertainty of the LULUCF accounting conducted based on aggregate regional statistics, and exaggeration of the extent to which Russian forests are "managed" ${ }^{25}$, to its assigned amount in the second commitment period. This is shown in Table 2.3 below.

Table 2.3: The Impact of Various Unrestricted Accounting Rules on Russia's Assigned Amount

\begin{tabular}{|c|c|c|c|c|}
\hline & Gross/Net & $\begin{array}{l}\text { Net/Net } \\
1990\end{array}$ & $\begin{array}{l}\text { Net/Net } \\
2001-2005\end{array}$ & Bar-to-Zero 1990 \\
\hline $\begin{array}{l}\text { Percentage of } \\
1990 \text { emissions } \\
\text { i.e. } 1^{\text {st }} \text { commit- } \\
\text { ment period } \\
\text { AAUs }\end{array}$ & $11 \%$ & $5.6 \%$ & $2.4 \%$ & $5.6 \%$ \\
\hline $\begin{array}{l}\mathrm{Mt} \mathrm{CO}_{2} \mathrm{e}-\text { could } \\
\text { be added to } \\
\text { Russian assigned } \\
\text { amount }\end{array}$ & 365 & 186 & 80 & 186 \\
\hline $\begin{array}{l}\text { Description of } \\
\text { accounting } \\
\text { method }\end{array}$ & $\begin{array}{l}\text { Total net } \\
\text { carbon flux } \\
\text { during commit- } \\
\text { ment period }\end{array}$ & $\begin{array}{l}\text { Total net } \\
\text { carbon flux } \\
\text { during commit- } \\
\text { ment period } \\
\text { compared to } \\
1990 \text { carbon } \\
\text { flux }\end{array}$ & $\begin{array}{l}\text { Total carbon } \\
\text { flux during } \\
\text { commitment } \\
\text { period com- } \\
\text { pared to } 2001- \\
2005 \text { average } \\
\text { net carbon flux }\end{array}$ & $\begin{array}{l}\text { Debits are not } \\
\text { accounted for if } \\
\text { the net carbon } \\
\text { flux drops } \\
\text { below the } \\
\text { baseline. }\end{array}$ \\
\hline
\end{tabular}

Source: A Submission on LULUCF, the Russian Federation, 30 October 2009, Table 2.

${ }^{22}$ This section contributed by Thomas Spencer.

${ }^{23}$ Report of the Ad Hoc Working Group on Further Commitments for Annex I Parties under the Kyoto Protocol on its tenth session, held in Copenhagen from 7 to 15 December 2009, pp. 28. Available at: http://unfccc.int/resource/docs/2009/awg10/eng/17.pdf

${ }^{24}$ Emissions are subtracted from removals annually, and the net amount is credited or debited with reference to net removals in a base year or base period.

${ }^{25}$ Anna Korppoo and Thomas Spencer (2009). The Layers of the Doll: Exploring the Russian Position for Copenhagen. FIIA Briefing Paper 46, 5 November 2009. The Finnish Institute of International Affairs. 
The bar-to-zero and net-net accounting can coexist; the bar-to-zero merely allows a country not to account for debits from its assigned amount in the event that the net carbon flux drops below the baseline. Under gross-net accounting, $11 \%$ of Russia's 1990 emissions equate to ca. $365 \mathrm{Mt} \mathrm{CO}$, which could theoretically be added to the Russian assigned amount. Under net-net accounting with a 1990 base year ca. one third to one fifth of Russia's 2020 emissions reduction target (5.6\% of the 1990 level) could theoretically be achieved via LULUCF. In the likely event that Russia easily meets or exceeds its emissions reduction target, these unused Emissions Removal Units (RMUs) could be exchanged for Assigned Amount Units (AAUs) and then banked for future commitment periods. This would add to Russia's surplus of AAUs.

The results shown in Russia's LULUCF submission are supported by modeling work done by the European Commission.

Table 2.4 The Impact of Different, Unrestricted Accounting Rules on Russia's Assigned Amount

\begin{tabular}{lccc}
\hline Accounting Options & Kyoto Rules & $\begin{array}{r}\text { Net-Net } \\
\mathbf{1 9 9 0}\end{array}$ & $\begin{array}{r}\text { Net-Net } \\
\mathbf{1 9 9 0 - 1 9 9 9}\end{array}$ \\
\hline $\begin{array}{l}\text { Impact on the Russian Assigned Amount (\% of 1990 } \\
\text { emissions) }\end{array}$ & $3.6 \%$ & $7.3 \%$ & $0.8 \%$ \\
$\begin{array}{l}\text { Mt } \mathrm{CO}_{2} \mathrm{e}-\text { could be added to Russian assigned } \\
\text { amount }\end{array}$ & $121^{*}$ & 242 & 27 \\
\hline
\end{tabular}

Source: Based on The Commission of the European Communities (2009), "Towards a comprehensive climate change agreement in Copenhagen, Part 1, Extensive Background Information", pp. 56.

* The Marrakech Accords (FCCC/CP/2001/13/Add.1, Decision 12/CP.7) allocated Russia 33 Mt C under Article 3.4.

Differences between the two results may be due to the fact that the Russian submission employed projected emissions and sequestrations from the LULUCF sector, whereas the EU Commission merely extrapolated historical emissions from the LULUCF sector. If emissions and sequestrations did not develop as projected in the Russian submission, e.g. due to over-optimistic harvest forecasts, the impact on the Russian assigned amount would be larger, as seen in the Commission's calculations.

Within the UNFCCC climate talks, Russia is strongly against the use of caps and discounts for the LULUCF sector. As seen above, unrestricted accounting for the LULUCF sector could have a significant impact on Russia's emissions target and its potential surplus of emissions rights. At the same time, high uncertainty with monitoring emissions and sequestrations 
warrant the use of caps and discounts to limit the impact of windfall credits from this sector on developed country targets.

The most recent submission on LULUCF for Russia represents the results of a comprehensive reform of its accounting methodology, conducted under the auspices of the review by the Expert Review Team of its most recent National Inventory. The new accounting methodology smoothes out the interannual variability seen 1990-2008, and lowers the proposed reference level from -177.8 $\mathrm{Mt} \mathrm{CO}_{2} \mathrm{e}$ to $-89 \mathrm{Mt} \mathrm{CO}_{2} \mathrm{e}$. This in turn would increase the level of windfall credits gained, assuming that annual sequestrations 2012-2020 are higher than this proposed reference level and that no cap or discount is applied. Given that the Russian Federation is predicting annual average sequestrations of $420.1 \mathrm{Mt} \mathrm{CO}_{2} \mathrm{e}$ for the period 2012-2020, it would receive an average annual addition to its assigned amount of roughly $331.0 \mathrm{Mt} \mathrm{CO}_{2} \mathrm{e}$, or roughly $10 \%$ of 1990 emissions under such accounting rules. ${ }^{26}$ In this context, Russia has clearly indicated at the most recent negotiating session that its $15 \%$ target is "without proper accounting of LULUCF", and that its 25\% target is with full accounting for LULUCF, i.e. reference level of 1990 sequestrations and no cap or discount on forest management (figure 2).

\footnotetext{
${ }^{26}$ Предложения по Специальной рабочей группе по дальнейшим обязательствам для Сторон, включенных в Приложение I Киотского протокола, Землепользование, изменение землепользования и лесное хозяйство, 07.05.2010, Available at: http:/unfccc.int/files/ meetings/ad_hoc_working_groups/kp/application/pdf/russia_lulucf_may2010.pdf
} 


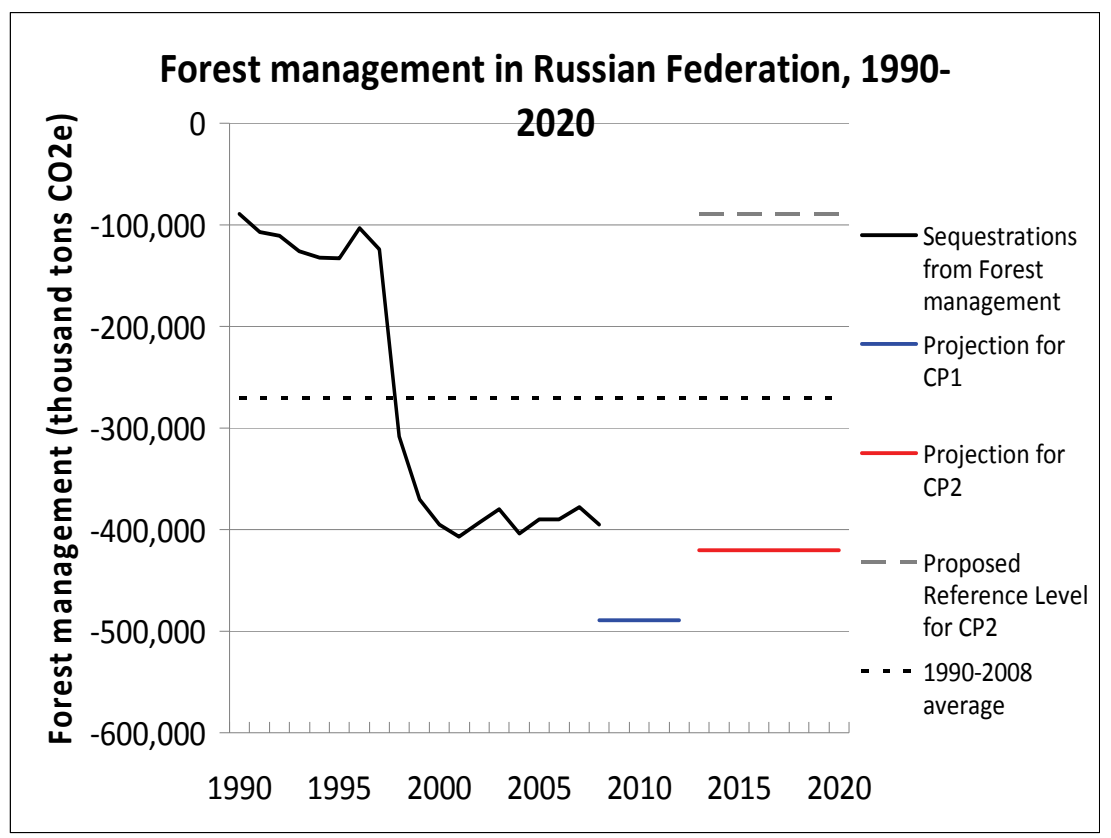

Figure 2: Historical and Projected Sequestrations from Forest Management in the Russian Federation; Projections for Commitment Periods 1 (CP1, 2008-2012) and 2 (CP2, 2013-2020) and Russia's Proposed Reference Level for CP2 


\section{Balancing the Russian pledge within a future agreement}

\subsection{Prospects for a deeper pledge}

Various Russian and foreign modeling scenarios arrive at a similar "no-lose" emission trend around 20-25\% below 1990 levels by 2020. This section compares the modeling work outlined in Section 1 to other independent modeling work to establish how deep a pledge Russia could adopt.

Internationally, Russia has been studied alone or as a part of the Former Soviet Union in models with a global coverage including the Fourth Assessment Report of the Intergovernmental Panel on Climate Change, World Energy Outlook of the International Energy Agency, Annual/Short-term Outlooks of the Energy Information Administration of the Department of Energy of the USA, and the IIASA.

Table 2.5 Overview of modeling and scenario work on Russia emissions

\begin{tabular}{lll}
\hline Source & $\begin{array}{l}\text { No-regret emissions } \\
\text { by } 2020\end{array}$ & Remarks \\
\hline IEA: WEO & $-23 \% *$ & \\
EIA & $-19 \% *$ & World Energy Projections Plus 2009 \\
IIASA & $-23 \% /-27 \%$ & MERGE E3 model \\
CENEf & $-10 \% /-20 \% *$ & ENERGYBAL-GEM 2050 model \\
Novikova et al. high GDP & $-25 \% /-30 \% \star \S$ & Scenario approach \\
Novikova et al. low GDP & $-33 \% /-37 \% \star \S$ & Scenario approach \\
HSE - Section 1 & $-25 \% /-35 \% \star \S$ & RU-TIMES model, estimates based on official \\
& & economic development projection \\
\hline
\end{tabular}

Sources: IEA (2009), How the energy sector can deliver on a climate agreement in Copenhagen: Special early excerpt of the World Energy Outlook 2009 for the Bangkok UNFCCC Meeting; Energy Information Administration (2009), International Energy Outlook 2009; Digas et al. (2009), On Costs and Benefits of Russia's Participation in the Kyoto Protocol, IR-09-001, IIASA; Bashmakov (2009), Nizkouglerodnaya Rossija in 2050, Center for Energy Efficiency (CENEf), Novikova et al. (2009).

$\S$ economic crisis taken into account

* energy-related emissions only 
Domestically, there are two main research groups that conduct studies in this field, namely the Center for Energy Efficiency of Russia (CENEf) ${ }^{27}$ and the Moscow Higher School of Economics. The modeling results of the latter were reported in Section 1. The former uses the ENERGY-GEM model to 2050 to investigate only $\mathrm{CO}_{2}$ emissions from the energy sector (all fossil fuel combustion), and produced a range of scenarios. The most likely "noregret" scenario, "carbon plateau”, foresees a reduction of emissions by 10 $20 \%$ of 1990 level by $2020 .{ }^{24}$

Beyond these models, Novikova et $\mathrm{al}^{28}$ used a scenario approach in order to explore the potential impacts of the existing energy efficiency ${ }^{29}$ and renewable energy policies ${ }^{30}$ to emissions. With a $4 \%$ GDP growth assumption, $33 \%$ pledge is likely to represent the no-regret option since it can be achieved with the autonomous energy efficiency improvement of the economy without significant changes in fuel mix i.e. even if the energy efficiency and renewable energy policies failed. Significantly higher GDP growth (6.6\% by 2020) would have to be assumed in order to "reach" the current Russian pledge of 25\% below 1990 level by 2020 under such policy failure option. Under the assumption of $4 \%$ GDP growth, ca. $40 \%$ limitation of 1990 level emissions by 2020 is likely to represent a business-as-usual scenario should these policies be implemented successfully.

As shown in Table 2.5, a 20\% reduction of emissions seems to be the business as usual trend supported by most of the studies, while some are suggesting even deeper trends. Further, most modeling work has not taken into account the recent economic crisis, and most of the models cover energy sector emissions only. This leads to higher emission estimates in comparison to total emissions since many of the non-energy sectors' emissions have declined in Russia.

Also some energy sector trends and energy policies support such emission trends. The level of Russian energy intensity has been steadily falling since 1998, especially fast in the 2000s, due to the changes of the Russian

\footnotetext{
${ }^{27}$ Bashmakov, I. Lowcarbon Russia: 2050. Cenef: Moscow.

${ }^{28}$ Novikova, Aleksandra; Anna Korppoo and Maria Sharmina (2009). "Russian pledge vs. business-as-usual: Implementing energy efficiency policies can curb carbon emissions’, UPI Working Paper 61, 4 December 2009. http://www.upi-fiia.fi/fi/publication/97/.

29 о некоторых мерах по повышению энергетической и экологической эффективности российской экономики, Order of the President, N889, 4 June 2008.

${ }^{30}$ Decree No. 1-r. Guidelines for State Policy of Energy Efficiency Increase through Use of Renewables for the Period up to 2020, 8 January 2009.
} 
economy rather than any specific policies and measures. ${ }^{31}$ The "until 2020" Energy Strategy estimated that Russia's has a potential to save some 39$47 \%$ of its current energy consumption. ${ }^{32}$ Bashmakov et al have estimated the technical energy efficiency potential to be almost 400 mtoe. $^{33}$

The energy efficiency legislation is aimed at fulfilling the official target to cut energy intensity by $40 \%$ during 2007-2020. It envisages various concrete economic incentives to realize this potential.

Such emissions-reducing policies are introduced in order to improve the competitiveness and economic efficiency of the Russian economy, and due to the dubious reputation of climate policy in Russia traditionally rather labeled as energy than climate policies. However, President Medvedev has recently been linking these modernization policies to climate policies arguing that they will be implemented in any case and that they are in national interest. $^{34}$

Given the perceived legitimacy of the systemic change related emission collapse, participating in an international climate agreement is unlikely to influence the Russian emission trends. Therefore, the best approach to the Russian contribution to the global climate regime is to examine the emission trends expected based on business as usual policies.

\subsection{Balancing the architecture of the agreement}

If Russia is allowed to adopt the currently offered -15 / -25\% target until 2020, in order to reach the 25-40\% emission reduction from Annex I, other members will have to absorb the Russian allowance with deeper targets. In addition, the impact of the surplus carry-over must be taken into account, either by absorbing it as well, or finding an architectural solution to limit its use beyond 2012. If divided evenly over the 2013-2020 period, this would lead to an additional emission reduction of $730-1,000$ Mt per annum by

\footnotetext{
${ }^{31}$ Tulinov, Sergey, Presentation by the Russian Federation on Mitigation Potentials, 3 December 2008, Poznan. Kulagin, Vyacheslav, “Energy Efficiency and Development of Renewables: Russia’s Approach”, Russian Analytical Digest, vol. 46/08, 25 September 2008.

${ }^{32}$ Kulagin, Vyacheslav, “Energy Efficiency and Development of Renewables: Russia's Approach”, Russian Analytical Digest, vol. 46/08, 25 September 2008.

${ }^{33}$ See Annex 1 for more detailed information.

${ }^{34}$ Medvedev, Dmitri, Opening Remarks at Security Council Meeting on Climate Change, 17 March 2010. Available at http://eng.kremlin.ru/text/speeches/2010/03/17/1931_type82913_224806. shtml
} 
other Annex I parties, if the size of surplus is projected to be 5.1-7 Gt over the first commitment period. This is equivalent to, for instance, some 15$20 \%$ of the EU emissions in 1990.

An architectural solution for the surplus could be based on various approaches, including limitations to the carry-over of the surplus, limitations to the use of the surplus carried over both ex-ante and ex-post, and abolishing the surplus.

Carry-over of the surplus could be limited by discounting the amount transferred. The use of the surplus carried over could be limited ex-ante by various means, including restricting the use of the surplus to domestic compliance, or even domestic compliance beyond 2020 only, or allowing its use only through a Green Investment Scheme. ${ }^{35}$ Ex-post, the use of the surplus could also be limited by auto-regulation i.e. an agreement between potential buyers to refrain from using the surplus to offset domestic emissions. The latter could be politically easier to establish as the agreement by the surplusholding countries would not be necessary, however, the former approaches could provide legally firmer solutions to the problem.

For a fair architectural solution, it would be logical to treat all Annex I transition economies equally. Given their shared characteristics (some of them shown in Table 2.2) and interests, and the surplus problem they are linked to, recognizing them as a separate country group may be part of the solution. Retaining the transition economy status, perhaps also including the voluntary nature of the financial contributions of this country group, could provide an incentive to establish such a country group. Further, as one of the main concerns of the transition economy parties is securing their future economic growth by allowing headroom for the growth of emissions, an architectural solution for holding some of the surplus in case it would be needed for this purpose could be an option to explore. This could also allow a politically acceptable solution to the feeling of entitlement for the surplus, unlike banning its transfer altogether.

A non-AAU based system - as suggested by the United States - has been mentioned as a possible solution to the surplus problem: the surplus would disappear together with the AAUs. However, this would be unlikely to change the feeling of entitlement transition economies hold for their surpluses as a compensation for the collapse of their economies. Further, the absence of

\footnotetext{
${ }^{35}$ Korppoo, Anna and Spencer, Thomas (2009). The Dead Souls: How to Deal with the Russian Surplus? Briefing Paper 39, 4 September 2009, the Finnish Institute of International Affairs.
} 
AAUs would require a re-design of the whole global climate regime established by the Kyoto Protocol, and in effect, make a lot of the institutional work done under the Kyoto Protocol redundant.

The use of caps and discounts to limit the impact of windfall credits from the LULUCF sector are under discussion, and in the light of the dynamics of the negotiations it seems plausible that some restrictions will be imposed on LULUCF. ${ }^{36}$ Although LULUCF is a highly politicized issue, Russia may be able to accept this, as it has no real need to extra credits to meet its current target.

Which ever elements of the future agreement are chosen to be balanced in order to prevent the environmentally detrimental impact of the Russian participation in the regime, it is important to have a clear idea of the level of emission reduction to be achieved in real terms when all the flexibilities are taken into account.

\footnotetext{
${ }^{36}$ The G77 and China country group is advocating strongly for this.
} 



\section{Potential external trade-offs}

\subsection{Feasibility of trade-offs}

Given the political sensitivity of the gentlemen's agreement over Russia's WTO membership between Russia and the EU to support the ratification of the Kyoto Protocol, the whole idea of swapping the future climate deal to an external trade-off remains risky, and should be avoided if possible.

It also has to be considered when the external trade-offs may be the most useful. The outcome of the Copenhagen negotiations illustrate that the chances of establishing a legally binding climate regime on short term may be slim, and therefore, it is too early to discuss external trade-offs to persuade Russia to join; this was also the Russian approach in Copenhagen. ${ }^{37}$

It also ought to be asked why Russia should not join in any case. If dropping out of the Copenhagen deal, Moscow would be excluded from a lot of global energy sector decision-making. Also, a positive foreign policy role has been an important element of the Russian motivation to participate in international climate policy in the past.

\subsection{Potential trade-offs}

Relaxing the visa regime between EU and Russia: EU-Russia visa freedom has been a longer-term issue for some time and with no timetable set for further liberalization. The issues hindering liberalization include meager support for such visa freedom domestically in the EU, the feeling that Russia would gain more from the visa freedom than the EU, the fears of Russian passports spreading to the Northern Caucasus, losing control over migration,

\footnotetext{
${ }^{37}$ Ведомости, 7 December 2010. Подарок от России.
} 
and technical concerns such as the lack of Russian population register. True Russian willingness to open its borders to foreigners has also been questioned as the country sticks to its registration requirement for people entering Russia; this treatment goes against the principle of reciprocity of the visa regimes. $^{38}$

Russia has certainly stated clearly that it is ready to start preparing for a visa freedom with the EU. ${ }^{39}$ However, the diminishing civil rights of the Russian citizens invites the question of the leadership's prepared-ness to open door for more freedom to travel. However, some mutual interests have been found on this issue between Russia and the EU, and therefore, linking them to the future climate agreement may be feasible.

An update of the Energy Charter Treaty: President Medvedev has suggested to the EU to abandon the Energy Charter Treaty (ECT), arguing that the treaty is biased towards consumers ${ }^{40}$, and the Russian-Ukrainian gas dispute provided evidence of the dysfunctional nature of the treaty. ${ }^{41} \mathrm{He}$ has outlined the replacement as Energy Security Cooperation Protocol ${ }^{42}$ and Russia has started the process of withdrawing the ECT. ${ }^{43}$ The EU has rejected this proposal as a replacement of the $\mathrm{ECT}^{44}$; it has been argued that beyond additional elements of the producers' perspective and discipline on transit rights, Russia aims at establishing a treaty which puts little constraints on anyone in order to avoid strong protection of foreign investors active on the Russian energy sector. Sidelining the ECT would serve the same purpose; the applicability of the

${ }^{38}$ Salminen, Minna-Mari \& Moshes, Arkady (2009). Practice what you preach: the prospects for visa freedom in Russia-EU relations. FIIA Report 18.

${ }^{39}$ Russia says ready for visa-free regime with EU, Moscow News 11 December 2008. Available at http://www.mnweekly.ru/news/20081211/55360692.html. Accessed 17 November 2009.

${ }^{40}$ Russia’s Medvedev says to present new energy charter, Reuters 1 March 2009. Available at http://uk.reuters.com/article/idUKL152339820090301. Accessed 17 November 2009.

${ }^{41}$ European Voice 14 May 2009, Medvedev to renew call for energy treaty at summit. Available at http://www.europeanvoice.com/article/imported/medvedev-to-renew-call-forenergy-treaty-at-summit/64862.aspx. Accessed 16 November 2009.

42 Концептуальный подход к новой правовой базе международного сотрудничества в сфере энергетики (цели и принципы). http://tours.kremlin.ru/text/docs/2009/04/215303.shtml. Accessed 18 November 2009. Russia invites Europe to join new energy charter, EUObserver.com 21 April 2009. Available at http://euobserver.com/9/27970. Accessed 17 November 2009.

${ }^{43}$ Russia Rejects Energy Charter Treaty: A New Era for Investment Arbitration? International Law Office 22 October 2009. Available at http://www.internationallawoffice.com/ Newsletters/Detail.aspx?g=17675c7c-c55e-4f1d-81cd-e5610fd3b3d8. Accessed 17 November 2009.

${ }^{44}$ EU rejects Russia proposal to replace Energy Charter, 30 April 2009. Available at http://www.eubusiness.com/news-eu/1241089322.03/. Accessed 16 November 2009. 
treaty to Russia, which has signed but not ratified the treaty, is under scrutiny as the imprisoned ex-oil tycoon Khodorkovski's legal team has made a complaint against Russia based on the ECT rules. Ruling against Russia could bring up also other complaints by investors based on violating the ECT rules. $^{45}$

Linking an update of the Energy Charter Treaty to the future climate agreement could address gas transit problems relevant to both Russia and the EU, and build on president Medvedev's initiative. However, serious concerns have been raised on the Russian interests in the process.

Long-term gas contracts between Russia and the EU: Long-term "take-orpay" gas contracts based on oil price developments over 25 or even 30 years, have been a standard between Gazprom and the large European gas buyers; this has provided the gas producer a security of demand to support long-term investments in new gas fields.

Recently, various dynamics have influenced the gas market. First, liquefied natural gas (LNG) infrastructure enables transporting gas long distances beyond pipelines, and thus, contributes to the formation of international gas price formation. Second, the economic crisis has declined gas demand in Europe while new gas supplies, for instance, due to the engineering advances to utilize shale rock in the US instead of exports, have become available. As shown in Figure 2.3, in the future it is estimated to be cheaper to import gas to the EU from elsewhere than the Russian north. Third, the traditional link of gas price to oil price seems out-of-date. ${ }^{46}$

\footnotetext{
${ }^{45}$ Erixon, Fredrik, Medvedev Unveils the New Energy Treaty, 23 April 2009. Available at http://www.ecipe.org/blog/medvedev-unveils-his-new-energy-treaty. Accessed 17 November 2009.

${ }^{46}$ U.S. Gas Fields Go From Bust to Boom, Wall Street Journal 30 April 2009. Available at http://online.wsj.com/article/SB124104549891270585.html. Accessed 16 November 2009. "Huge” gas field found off Brazil, BBC 22 January 2008. Available at http://news.bbc.co.uk /2/hi/americas/7201744.stm. Accessed 16 November 2009. Gazprom, Europe, and long-term take-or-pay contracts, 2 November 2009. Available at http://knowledgeproblem.com/2009/ 11/02/gazprom-europe-and-long-term-take-or-pay-contracts/. Accessed 17 November 2009. Stern, Jonathan (2009). Continental European Long-Term Gas Contracts: is a transition away from oil product-linked pricing inevitable and imminent? NG 34, Oxford Institute for Energy Studies, September 2009.
} 


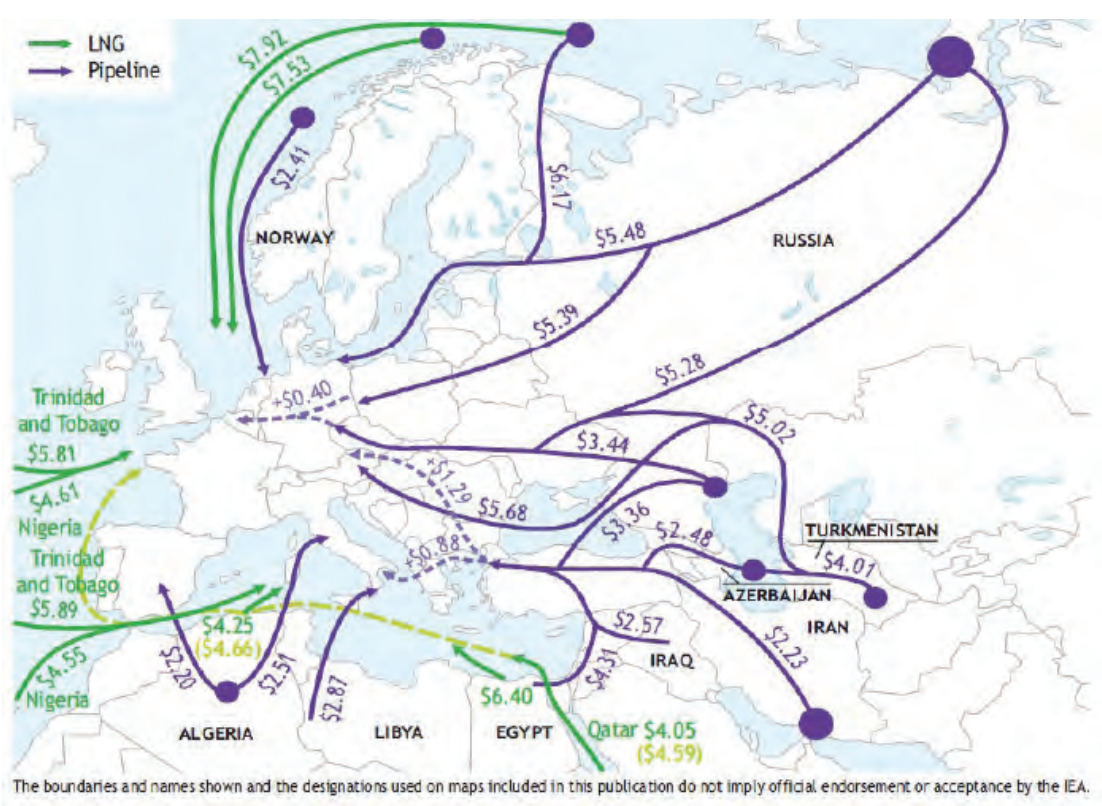

Figure 2.3 Indicative costs of potential new sources of gas delivered to Europe 2020, USD/MBtu

Source: World Energy Outlook 2009, presentation to the press, London 10 November 2009.

European customers have recently been falling short of the minimum amount of gas they have contracted to buy from Gazprom. ${ }^{47}$ It has been suggested that Moscow could be persuaded to sign up to the future climate agreement against long-term gas contracts with European customers. However, given the above dynamics of the gas markets recently, due to the IEA estimates that climate policies could start curbing gas demand in Europe as early as $2025^{48}$ and for gas dependency reasons, such a trade-off with Russia does not seem attractive for the EU.

Further ideas raised as potential trade-offs include revisiting the Russian WTO membership, however, this issue is likely to bring back negative memories related to the Kyoto ratification deal perceived as a failure by Russia. Fur-

\footnotetext{
${ }^{47}$ Gazprom, Europe, and long-term take-or-pay contracts, 2 November 2009. Available at http://knowledgeproblem.com/2009/11/02/gazprom-europe-and-long-term-take-or-pay-contracts/. Accessed 17 November 2009.

${ }^{48}$ World Energy Outlook 2009, presentation to the press, London 10 November 2009. Green policies expected to hit gas demand, Financial Times 4 November 2009. Available at http://www. ft.com/cms/s/0/114e6ac2-c97e-11de-a071-00144feabdc0.html?catid=20\&SID=google.
} 
ther, finding a solution to the Russian-Ukrainian gas crisis was raised as a potentially common interest for Russia and the EU. However, it is less relevant at the moment as Ukraine and Russia have no open major disputes. None of these trade-off options seem obviously superior; their relevance very much depends on the timing when such deals may be necessary. 



\section{Bibliography}

Bashmakov I., Low Carbon Russia: 2050. Moscow, CENEF, 2008 (in Russian).

Bezrukih P.P. ed. (2007) Spravochnik resursov vozobnovljaemyh istochnikov jenergii Rossii. Spravochnik — katalog, 272 p. (In Russian)

BOFIT Venäjätilastot 5 March 2010. http://www.bof.fi/bofit/seuranta/venajat ilastot/.

Bushuev V., Troitsky A., Energy - 2050. Moscow, Institute of energy strategy, 2007, 72 p. (in Russian)

Current state and development perspectives of bio-energy in Russia. Workshop materials, 10 Sep 2008, Moscow. http:// www.e-apbe.ru/actions/detail.php?ID $=10950$

Current state and development perspectives of small hydro power plants in Russia. Workshop materials, 26 June 2008, Moscow. http://e-apbe.ru/actions/ detail.php?ID=8097

Current state and development perspectives of wind power plants in Russia. Workshop materials, 27 May 2008, Moscow. http://e-apbe.ru/actions/ detail.php?ID=7048

Deutsche Bank Research, Russia in the Financial Crisis and Beyond. 11 December 2009. p.12. Sutela, Pekka, Venäjä tuskin toipuu nopeasti at Venäjä ja kansainvälinen rahoituskriisi. BOFIT Online 2/2009

Dvorkovich; Roadmap of further talks to be adopted at Copenhagen climate conference; Interfax, 8 December 2009

EIA (2009) World Energy Outlook. Elektroenergetika Rossii 2030. tselevoe videnie (Electricity Sector of Russia 2030: Targeted Vision),
Eds.B.Vaizinkher. - Moscow, Alpina Business Books, 2008 (In Russian).

Elzen, Michel et al; "Pledges and Actions: A scenario analysis of mitigation costs and carbon market impacts for developed and developing countries", The Netherlands Environmental Assessment Agency, 2009.

Entov R., Lugovoy O., Astafeva Ye., at al; Factors of Economic Growth in Russia’s Economy. Working papers \# 70, IET, Moscow, 2004.

Erixon, Fredrik; Medvedev Unveils the New Energy Treaty, 23 April 2009. Available at http://www.ecipe.org/blog/ medvedev-unveils-his-new-energytreaty

EU Business, EU rejects Russia proposal to replace Energy Charter, 30 April 2009, http://www.eubusiness.com/ news-eu/1241089322.03/.

EU Observer.com, Russia invites Europe to join new energy charter, 21 April 2009. Available at http://euobserver. com/9/27970. Accessed 17 November 2009

European Voice 14 May 2009, Medvedev to renew call for energy treaty at summit. http://www.europeanvoice.com/ article/imported/medvedev-to-renewcall-for-energy-treaty-at-summit/64862. aspx.

Financial Times; Green policies expected to hit gas demand, 4 November 2009. http://www.ft.com/cms/s/0/114e6ac2c97e-11de-a071-00144feabdc0. html catid=20\&SID=google

General schema of dislocation of electric energy objects, 2008. http://www.eapbe.ru/scheme/gs.doc 
The Human Development Index

2007/2008; Joint submission by Australia, Belarus, Canada, Croatia, the European Community and its Member States, Iceland, Japan, Kazakhstan, Liechtenstein, Monaco, New Zealand, Norway, Russian Federation, Switzerland, Ukraine to AWG-LCA and AWG-KP, 9 October 2009.

IEA (2008) Energy Technology Perspectives 2008 - Scenarios and Strategies to 2050, 650 p.

International Energy Outlook 2009;

Digas et al. (2009).

Kleimenov, K., "Conversation between

Dmitry Medvedev and Director of

News Programmes at Russias ${ }^{1}$ Channel

One”, http://www.kremlin.ru/eng/ speeches/2009/06/18/1241_type82916_ 218210.shtml.

International Law Office, Russia Rejects Energy Charter Treaty: A New Era for Investment Arbitration? International Law Office 22 October 2009. http:// www.internationallawoffice.com/News letters/Detail.aspx?g=17675c7c-c55e4f1d-81cd-e5610fd3b3d8.

The Knowledge problem; Gazprom, Europe, and long-term take-or-pay contracts, 2 November 2009. http://knowledgeproblem.com/2009/11/02/ gazprom-europe-and-long-term-takeor-pay-contracts/

Kokorin A., Garnak A., Gritsevich I., Safonov G., Economic Development and Climate Change. Moscow, DEPA, 2008. - 32 p. (in Russian).

Koncepcija energeticheskoj strategii Rossii na period do 2030 goda. (Proekt). (Prilozhenie k obwestvennodelovomu zhurnalu «Jenergeticheskaja politika»). 2007 g., 116p.

Korppoo, Anna; Jakobson, Linda; Urpelainen, Johannes; Vihma, Antto and Luta, Alex (2009). Towards a new climate regime? Views of China, India, Japan, Russia and the United States on the road to Copenhagen. FIIA report 19, the Finnish Institute of International Affairs.

Korppoo, Anna and Spencer, Thomas (2009). The Dead Souls: How to Deal with the Russian Surplus? Briefing Paper 39, 4 September 2009, the Finnish Institute of International Affairs.

Korppoo, Anna and Spencer, Thomas (2009). The Layers of the Doll: Exploring the Russian Position for Copenhagen. FIIA Briefing Paper 46, 5 November 2009. The Finnish Institute of International Affairs.

Kulagin, Vyacheslav, "Energy Efficiency and Development of Renewables: Russia's Approach”, Russian Analytical Digest, vol. 46/08, 25 September 2008.

Laing, Tim; Junankar, Sudhir, Pollitt, Hector and Grubb, Michael, Global Carbon Mechanisms Annex II: Emissions and demand projections to 2020. Climate Strategies, March 2009.

Levin, Kelly \& Bradley, Rob (2010). Comparability of Annex I Emission Reduction Pledges. The World Resources Institute Working Paper, February 2010.

MEDT (2008) Concept of Long Run Socio-Economic development of the Russian Economy up to 2020. (Koncepcija dolgosrochnogo social'nojekonomicheskogo razvitija Rossijskoj Federacii na period do 2020 goda, In Russian). www.economy.gov.ru

Medvedev, Dmitry. Opening remarks at meeting on climate change, 18 February 2010. http://eng.kremlin.ru/text/ speeches/2010/02/18/1841_type82913_ 224384.shtm

Medvedev, Dmitri, Opening Remarks at Security Council Meeting on Climate Change, 17 March 2010. http://eng. kremlin.ru/text/speeches/2010/03/17/ 1931_type82913_224806.shtm

Moscow News, Russia says ready for visa-free regime with EU, 11 December 2008. http://www.mnweekly.ru/ news/20081211/55360692.html 
Novikova, Aleksandra; Korppoo, Anna and Sharmina, Maria (2009). 'Russian pledge vs. business-as-usual: Implementing energy efficiency policies can curb carbon emissions”, UPI Working Paper 61, 4 December 2009. http:// www.upi-fiia.fi/fi/publication/97/. OECD (2008), OECD Environmental Outlook to 2030.

President of Russia, Пресс-конференция по итогам 24-го саммита Россия-ЕС. Available at http://news.kremlin.ru/ transcripts/6034.

Rostat (2010). Национальные счета: валовой внутренний продукт. http://www.gks.ru/free_doc/new_site/v vp/tab3.xls

Reuters, Russia's Medvedev says to present new energy charter, 1 March 2009. http://uk.reuters.com/article/ idUKL152339820090301

Russian submission to the UNFCCC, 29 January 2010. http://unfccc.int/files/ meetings/application/pdf/ russiacphaccord_app1.pdf

Salminen, Minna-Mari \& Moshes, Arkady (2009). Practice what you preach: the prospects for visa freedom in Russia-EU relations. FIIA Report 18.

Stern, Jonathan (2009). Continental European Long-Term Gas Contracts: is a transition away from oil productlinked pricing inevitable and imminent? NG 34, Oxford Institute for Energy Studies, September 2009.

Suni, Paavo (2007). Oil Prices and the Russian Economy: Some Simulation Studies with NiGEM

TEK i ekonomika Rossii: VChERA SEGODNJa - ZAVTRA. Vzgljad iz 2007 g. (Ezhegodnyj obzor). 2007 g., p.212 (in Russian).

Tulinov, Sergey, Presentation by the Russian Federation on Mitigation Potentials, 3 December 2008, Poznan. Ku- lagin, Vyacheslav, “Energy Efficiency and Development of Renewables: Russia’s Approach”, Russian Analytical Digest, vol. 46/08, 25 September 2008. UNFCCC, Report of the Ad Hoc Working Group on Further Commitments for Annex I Parties under the Kyoto Protocol on its tenth session; Copenhagen, December 2009. http://unfccc.int/ resource/docs/2009/awg10/eng/17.pdf

Wall Street Journal Online, 14 December 2009, Russia Demands Its Credits.

Wall Street Journal Online, 30 April 2009, U.S. Gas Fields Go From Bust to Boom, http://online.wsj.com/article/ SB124104549891270585.html

WB \& IFC (2008) World Bank \& International Finance Corporation, Energy efficiency in Russia: Untapped Reserves, http://www.ifc.org/ifcext/ rsefp.nsf/AttachmentsByTitle/ FINAL_EE_report_Engl.pdf/\$FILE/ Final_EE_report_engl.pdf

World Bank (2009), World Development Report - 2010 http://www.un.org/ russian/esa/worlddev2010.pdf

World Bank 2009, Quoted in Mark Larzarowicz, "Global Carbon Trading: A framework for reducing emissions”, United Kingdom Department of Climate Change, June 2009.

World Energy Outlook 2009, Presentation to the press, London 10 November 2009.

Предложения по Специальной рабочей группе по дальнейшим обязательствам для Сторон, включенных в Приложение I Киотского протокола, Землепользование, изменение землепользования и лесное хозяйство, 07.05.2010. http://unfccc.int/ files/meetings/ad_hoc_working_groups/ kp/application/pdf/russia_lulucf_may20 10.pdf 



\section{Sammanfattning}

Vid förhandlingarna inom ramen för UNFCCC och Kyotoprotokollet avseende tiden efter 2012 aktualiserades en rad frågor om framtida åtaganden för industriländer och utvecklingsländer för att minska de globala utsläppen av växthusgaser. Resultatet av förhandlingsrundan i Köpenhamn - Köpenhamnsöverenskommelsen - blev ett övergripande mål som innebär att den globala uppvärmningen i genomsnitt ska understiga $2^{\circ} \mathrm{C}$ under 2000-talet. Enligt IPCC skulle det medföra att parterna enligt bilaga I måste minska sina utsläpp av växthusgaser med 25-40 \% fram till 2020.

Ryssland var år 2007 den tredje största utsläpparen av växthusgaser i världen efter Kina och USA. Landets utsläpp minskade avsevärt efter Sovjetsystemets sammanbrott, från 3,3 miljoner ton $\mathrm{CO}_{2} \mathrm{e} 1990$ till 2,2 miljoner ton $\mathrm{CO}_{2} \mathrm{e}$ 2007. Den ekonomiska krisen 2009 ledde till ytterligare minskningar av utsläppen. I Köpenhamnsöverenskommelsen förband sig Ryssland att minska sina utsläpp med 15-25 \% under 1990 års nivå fram till 2020.

I den första delen av den här rapporten analyseras utvecklingstrender och förhållanden i den ryska ekonomin, särskilt inom energisektorn. Där behandlas även prognoserna för koldioxidutsläppen fram till 2020 och därefter, med utgångspunkt i regeringens olika ekonomiska utvecklingsscenarier. Det här är de viktigaste slutsatserna:

- I scenarierna förutses att utsläppen kommer att öka. Ryssland har emellertid fortfarande en oerhörd potential för att ytterligare minska utsläppen. Det gäller särskilt i den ineffektiva energisektorn och den offentliga sektorn, metallindustrin. Stor potential för att öka användningen av förnyelsebar energi och ökad koldioxidbindningen i skogar.

- En aktiv politik i områdena energieffektivitet, modernisering och innovationer skulle sannolikt leda till en stabilisering av utsläppen vid 27-35 \% under 1990 års nivåer år 2020. 
- RU-TIMES modell som är inriktad på el- och värmeproduktion visar att stränga utsläppstak och kopplingar till den globala koldioxidmarknaden skulle kunna minska utsläppen från den här sektorn med omkring 50 \% under 1990 års nivå fram till 2020 och med 54 \% fram till 2030.

Den andra delen av rapporten behandlar Rysslands position i förhandlingsprocessen om en klimatordning efter 2012, däribland landets åtaganden om utsläppsbegränsningar, överföring av överskott av utsläppsrätter (AAU) efter 2012 och koldioxidsänkor i skogar. De viktigaste slutsatserna är följande:

- Synen på Rysslands utsläppstrend om inga åtgärder vidtas varierar. Om hänsyn tas till den ekonomiska krisen tycks dock 30-35 \% under 1990 års nivå år 2020 vara en sannolik utveckling. Det innebär att det nuvarande åtagandet om - $25 \%$ kan anses svagt.

- I kombination med överföring av överskottet och de beräkningsregler för koldioxidsänkor i skogar som Moskva förespråkar, skulle Rysslands åtagande enligt Köpenhamnsöverenskommelsen kräva att andra bilaga I-länder accepterade mål som ligger bortom deras nivåer för jämförbara insatser i gruppen som helhet för att de totala utsläppsminskningar som IPCC rekommenderar ska kunna uppnås.

- Samtidigt har Rysslands utsläpp minskat sedan 1990 och "full” medräkning av skogar politiska prioriteringar för Moskva.

- Potentiella kompromisser för att få med Ryssland i klimatförhandlingarna har diskuterats (och använts under processen för ratificering av Kyotoprotokollet). Men det oklara läge i förhandlingarna som för närvarande råder innebär att tiden inte är mogen för sådana kompromisser. Med tanke på kopplingarna till den framtida globala energipolitiken finns det också anledning att fråga sig varför Ryssland inte skulle ansluta sig till systemet utan sådana kompromisser.

Den här rapporten bygger på en studie som genomfördes före klimatförhandlingsrundan i Köpenhamn i december 2009 och som uppdaterades i juni 2010. Analysen avspeglar emellertid inte helt och hållet den senaste tidens utveckling när det gäller den internationella klimatordningen. 


\section{Annex}

\section{Brief overview of RU-TIMES model}

RU-TIMES (an acronym for The Integrated MARKAL-EFOM System) is an economic model generator for local, national or multi-regional energy systems, which provides a technology-rich basis for estimating energy dynamics over a long-term, multi-period time horizon. It is usually applied to the analysis of the entire energy sector, but may also be applied to study in detail single sectors (e.g. the electricity and district heat sector).

Reference case estimates of end-use energy service demands (e.g., car road travel; residential lighting; steam heat requirements in the paper industry; etc.) are provided by the user for each region. In addition, the user provides estimates of the existing stock of energy related equipment in all sectors, and the characteristics of available future technologies, as well as present and future sources of primary energy supply and their potentials.

Using these as inputs, the RU-TIMES model aims to supply energy services at minimum global cost (more accurately at minimum loss of surplus) by simultaneously making equipment investment and operating, primary energy supply, and energy trade decisions, by region. For example, if there is an increase in residential lighting energy service relative to the reference scenario (perhaps due to a decline in the cost of residential lighting, or due to a different assumption on GDP growth), either existing generation equipment must be used more intensively or new - possibly more efficient equipment must be installed. The choice by the model of the generation equipment (type and fuel) is based on the analysis of the characteristics of alternative generation technologies, on the economics of the energy supply, and on environmental criteria. RU-TIMES is thus a vertically integrated model of the entire extended energy system. 
The scope of the model extends beyond purely energy oriented issues, to the representation of environmental emissions, and perhaps materials, related to the energy system. In addition, the model is admirably suited to the analysis of energy and environmental policies, which may be represented with accuracy thanks to the explicitness of the representation of technologies and fuels in all sectors.

In RU-TIMES - like in its MARKAL forebear - the quantities and prices of the various commodities are in equilibrium, i.e. their prices and quantities in each time period are such that the suppliers produce exactly the quantities demanded by the consumers. This equilibrium has the property that the total surplus is maximized.

The RU-TIMES model is particularly suited to the exploration of possible energy futures based on contrasted scenarios. Given the long horizons simulated with RU-TIMES, the scenario approach is really the only choice (whereas for the shorter term, econometric methods may provide useful projections). Scenarios, unlike forecasts, do not pre-suppose knowledge of the main drivers of the energy system. Instead, a scenario consists of a set of coherent assumptions about the future trajectories of these drivers, leading to a coherent organization of the system under study. A scenario builder must therefore carefully test the assumptions made for internal coherence, via a credible storyline.

In RU-TIMES, a complete scenario consists of four types of inputs: energy service demands, primary resource potentials, a policy setting, and the descriptions of a set of technologies.

In the case of the RU-TIMES model demand drivers (population, GDP, family units, etc.) are obtained externally, via other models or from accepted other sources. As one example, the RU-TIMES global model constructed for the EFDA2 used the GEM-E33 general equilibrium model to generate a set of coherent (total and sectoral) GDP growth rates in the various regions. Note that GEM-E3 itself uses other drivers as inputs in order to derive GDP trajectories. These GEM-E3 drivers consist of measures of technological progress, population, degree of market competitiveness, and a few other perhaps qualitative assumptions. For population and household projections, both GEM-E3 and RU-TIMES used the same exogenous sources (IPCC, Nakicenovic 2000, Moomaw and Moreira, 2001). Other approaches may be used to derive RU-TIMES drivers, whether via models or other means. 
For the EFDA model, the main drivers were: Population, GDP, GDP per capita, number of households, and sector GDP. For sectoral RU-TIMES models, the demand drivers may be different depending on the system boundaries. Once the drivers for a RU-TIMES model are determined and quantified the construction of the reference demand scenario requires computing a set of energy service demands over the horizon.

The demands are provided for the reference scenario. However, when the model is run for alternate scenarios (for instance for an emission constrained case, or for a set of alternate technological assumptions), it is likely that the demands will be affected. RU-TIMES has the capability of estimating the response of the demands to the changing conditions of an alternate scenario. To do this, the model requires still another set of inputs, namely the assumed elasticities of the demands to their own prices. RU-TIMES is then able to endogenously adjust the demands to the alternate cases without exogenous intervention. In fact, the RU-TIMES model is driven not by demands but by demand curves.

To summarize: the RU-TIMES demand scenario components consist in a set of assumptions on the drivers (GDP, population, households) and on the elasticities of the demands to the drivers and to their own prices.

The second constituent of a scenario is a set of supply curves for primary energy and material resources. Multi-stepped supply curves can be easily modeled in RU-TIMES, each step representing a certain potential of the resource available at a particular cost. In some cases, the potential may be expressed as a cumulative potential over the model horizon (e.g. reserves of gas, crude oil, etc), as a cumulative potential over the resource base (e.g. available areas for wind converters differentiated by velocities, available farmland for biocrops, roof areas for PV installations) and in others as an annual potential (e.g. maximum extraction rates, or for renewable resources the available wind, biomass, or hydro potentials). Note that the supply component also includes the identification of trading possibilities, where the amounts and prices of the traded commodities are determined endogenously (within any imposed limits).

As some policies impact on the energy system, they may become an integral part of the scenario definition. For instance, a No-Policy scenario may perfectly ignore emissions of various pollutants, while alternate policy scenarios may enforce emission restrictions, or emission taxes, etc. The detailed technological nature of RU-TIMES allows the simulation of a wide variety 
of both micro measures (e.g. technology portfolios, or targeted subsidies to groups of technologies), and broader policy targets (such as general carbon tax, or permit trading system on air contaminants). A simpler example might be a nuclear policy that limits the future capacity nuclear plants. Another example might be the imposition of fuel taxes, or of industrial subsidies, etc.

The fourth and last constituent of a scenario is the set of technical and economic parameters assumed for the transformation of primary resources into energy services. In RU-TIMES, these techno-economic parameters are described in the form of technologies (or processes) that transform some commodities into others (fuels, materials, energy services, emissions). In RU-TIMES, some technologies may be imposed and others may simply be available for the model to choose. The quality of a RU-TIMES model rests on a rich, well developed set of technologies, both current and future, for the model to choose from. The emphasis put on the technological database is one of the main distinguishing factors of the class of Bottom-up models, to which RU-TIMES belongs. Other classes of models will tend to emphasize other aspects of the system (e.g. interactions with the rest of the economy) and treat the technical system in a more succinct manner via aggregate production functions.

A model's structure exemplifies its fundamental approach for representing and analyzing a problem - it does not change from one implementation to the next. All RU-TIMES models exploit an identical mathematical structure. However, because RU-TIMES is data driven, each (regional) model will vary according to the data inputs. For example, in a multi-region model one region may, as a matter of user data input, have undiscovered domestic oil reserves. Accordingly, RU-TIMES generates technologies and processes that account for the cost of discovery and field development.

If, alternatively, user supplied data indicate that a region does not have undiscovered oil reserves no such technologies and processes would be included in the representation of that region's Reference Energy System (RES). Due to this property RU-TIMES can also be called a model generator that, based on the input information provided by the modeler, generates an instance of a model. In the following, if not stated otherwise, the expression model is used with two meanings: the instance of a RU-TIMES model or more generally the model generator RU-TIMES.

The structure of RU-TIMES is ultimately defined by variables and equations determined from the data input provided by the user. This information 
collectively defines each RU-TIMES regional model database, and therefore the resulting mathematical representation of the RES for each region. The database itself contains both qualitative and quantitative data. The qualitative data includes, for example, lists of energy carriers, the technologies that the modeler feels are applicable (to each region) over a specified time horizon, as well as the environmental emissions that are to be tracked. This information may be further classified into subgroups, for example energy carriers may be split by type (e.g., fossil, nuclear, renewable, etc). Quantitative data, in contrast, contains the technological and economic parameter assumptions specific to each technology, region, and time period. When constructing multi-region models it is often the case that a technology may be available for use in two distinct regions; however, cost and performance assumptions may be quite different (i.e., consider a residential heat pump in Canada versus the same piece of equipment in China). This chapter discusses both qualitative and quantitative assumptions in the RU-TIMES modeling system.

The RU-TIMES energy economy is made up of producers and consumers of commodities such as energy carriers, materials, energy services, and emissions. RU-TIMES, like most equilibrium models, assumes competitive markets for all commodities. RU-TIMES may, however, depart from perfectly competitive market assumptions by the introduction of user-defined explicit constraints, such as limits to technological penetration, constraints on emissions, exogenous oil price, etc. Market imperfections can also be introduced in the form of taxes, subsidies and hurdle rates.

Operationally, a RU-TIMES run configures the energy system (of a set of regions) over a certain time horizon in such a way as to minimize the net total cost (or equivalently maximize the net total surplus) of the system, while satisfying a number of constraints. RU-TIMES is run in a dynamic manner, which is to say that all investment decisions are made in each period with full knowledge of future events. The model is said to have perfect foresight (or to be clairvoyant). In addition to time-periods (which may be of variable length), there are time divisions within a year, also called timeslices, which may be defined at will by the user. For instance, the user may want to define seasons, day/night, and/or weekdays/weekends. Time-slices are especially important whenever the mode and cost of production of an energy carrier at different RU-TIMES of the year are significantly different. This is the case for instance when the demand for an energy form fluctuates 
across the year and a variety of technologies may be chosen for its production. The production technologies may themselves have different characteristics depending on the time of year (e.g. wind turbines or run-of-the-river hydro plants). In such cases, the matching of supply and demand requires that the activities of the technologies producing and consuming the commodity be tracked at each time slice.

Examples of commodities requiring time-slicing may include electricity, district heat, natural gas, industrial steam, and hydrogen. Two additional reasons for defining sub yearly time slices are a) the fact that the commodity is expensive (or even impossible) to store (thus requiring that production technologies be suitably activated in each time slice to match the demand), and $b$ ) the existence of an expensive infrastructure whose capacity should be sufficient to bear the peak demand for the commodity. The net result of these characteristics is that the deployment in time of the various production technologies may be very different in different time-slices, and furthermore that specific investment decisions be taken to insure adequate reserve capacity at peak.

The time horizon is divided into a (user-chosen) number of time-periods, each model period containing a (possibly different) number of years. For RU-TIMES each year in a given period is considered identical, except for the cost objective function which differentiates between payments in each year of a period. For all other quantities (capacities, commodity flows, operating levels, etc) any model input or output related to period t applies to each of the years in that period, with the exception of investment variables, which are usually made only once in a period5,. In this respect, RU-TIMES is similar to MARKAL but differs from the approach used in EFOM, where capacities and flows were assumed to evolve linearly between so-called milestone years.

The initial period is usually considered a past period, over which the model has no freedom, and for which the quantities of interest are all fixed by the user at their historical values. It is often advised to choose an initial period consisting of a single year, in order to facilitate calibration to standard energy statistics. Calibration to the initial period is one of the more important tasks required when setting up a RU-TIMES model. The main variables to be calibrated are: the capacities and operating levels of all technologies, as well as the extracted, exported, imported, produced, and consumed quantities for all energy carriers, and the emissions if modeled. 
In RU-TIMES years preceding the first period also play a role. Although no explicit variables are defined for these years, data may be provided by the modeler on past investments. Note carefully that the specification of past investments influences not only the initial period's calibration, but also the model's behavior over several future periods, since the past investments provide residual capacity in several years within the modeling horizon proper.

The RU-TIMES energy economy consists of three types of entities:

1. Technologies (also called processes) are representations of physical devices that transform commodities into other commodities. Processes may be primary sources of commodities (e.g. mining processes, import processes), or transformation activities such as conversion plants that produce electricity, energy-processing plants such as refineries, enduse demand devices such as cars and heating systems, etc,

2. Commodities consisting of energy carriers, energy services, materials, monetary flows, and emissions. A commodity is generally produced by some process(es) and/or consumed by other process(es), and

3. Commodity flows, that are the links between processes and commodeties. A flow is of the same nature as a commodity but is attached to a particular process, and represents one input or one output of that process.

The RU-TIMES model introduces further enhancements over and above those of MARKAL. In RU-TIMES, the horizon may be divided into periods of unequal lengths, thus permitting a more flexible modeling of long horizons: typically, one may adopt short periods in the near-term (the initial period often consists of a single base year), and longer ones in the out years; RU-TIMES includes both technology related variables (as in MARKAL) and flow related variables (as in the EFOM model, van der Voort et. al., 1984), thus allowing the easy creation of more flexible processes and constraints; the expression of the RU-TIMES objective function (total system cost) tracks the payments of investments and other costs much more precisely that in other bottom-up models; and, several other new features of RU-TIMES.

Detailed information on the RU-TIMES model can be found on the website of Energy Technology Systems Analysis Programme http://www. etsap.org/tools.htm 